University of North Florida

UNIVERSITY of

NORTH FLORIDA.

UNF Digital Commons

\title{
Assessing the Impact of Family Coaching on Parental Attitudes and Behaviors
}

James Young

University of North Florida

Follow this and additional works at: https://digitalcommons.unf.edu/etd

Part of the Education Commons

\section{Suggested Citation}

Young, James, "Assessing the Impact of Family Coaching on Parental Attitudes and Behaviors" (2007).

UNF Graduate Theses and Dissertations. 211.

https://digitalcommons.unf.edu/etd/211

This Doctoral Dissertation is brought to you for free and open access by the Student Scholarship at UNF Digital Commons. It has been accepted for inclusion in UNF Graduate Theses and Dissertations by an authorized administrator of UNF Digital Commons. For more information, please contact Digital Projects.

(c) 2007 All Rights Reserved

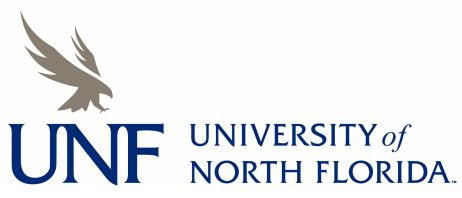


Assessing the Impact of Family Coaching on Parental Attitudes and Behaviors

$$
\text { by }
$$

$$
\text { James Young }
$$

\author{
A dissertation submitted to \\ the Doctoral Program Faculty in Educational Leadership \\ in partial satisfaction of the requirements \\ for the degree of \\ Doctor of Education \\ In Educational Leadership
}

UNIVERSITY OF NORTH FLORIDA

COLLEGE OF EDUCATION AND HUMAN SERVICES

Spring 2007

Unpublished work () James Young 
The dissertation of James Young is approved:

Signature Deleted

Cheryl Founthon, Ed.D., Cheir

\section{Signature Deleted}

Afesa Adahs, Ph.D.

\section{Signature Deleted}

Kogtuerine M, Kasten,.Ph,D.

Signature Deleted

Thomas S. Serwatka, Ph.D.

Accepting for the Department:

\section{Signature Deleted}

Joyec T. Jones, Ed.D., Chair

Departuent of Counscling and Educational Lcadership

Accepting for the College:

Signature Deleted

Larry G. Daniel, Fh.D, Dean

College of Education and Human Services

\section{Accepting for the University:}

Signature Déleted

David E.W, Fenner, Ph,D.

Dean, The Graduate School

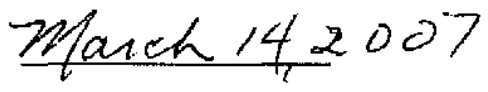

Mareh 14,2007

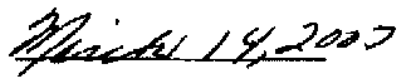

$M 10+c k=0,2007$

$\operatorname{may} 29,2007$

$3 / M+72007$ 


\section{Dedication}

This dissertation is dedicated

in loving memory to

my mother, Dorothy Young, and

my grandfather, Rev. Timothy Moore. 


\section{ACKNOWLEDGEMENTS}

I would like to thank God for giving me health and strength to complete this journey. Thank you to thank everyone, for putting up with me and motivating me throughout this process. Each of you played a part in the completion of this study. Without you I would have never reached this goal.

First, I would like to thank my mom, Dorothy Young, for instilling the importance of education and disciplining me for bringing home " $\mathrm{C}$ " grades in elementary. I certainly must thank my granddaddy for instilling in me the value of hard work, high expectations, and accomplishing my goals. I certainly thank my wife, Sonita, and my three kids, James II, Bryanna, and Timmy, for sacrificing the time I spent going to class, studying, rescarching, and writing this dissertation. I also like to thank my family in Atlanta, Georgia for their support, especially my sister Shakila Green and the family matriarch, my cousin Regina Walthour.

I offer many thanks to the staff at the University of North Florida who helped me get through this process. To Tom Serwatka and Cheryl Fountain for not allowing me to cut corners and taking the easy way out. To Afesa Adams for assuming the role of my mom by serving as a confidant throughout this process. Katherine Kasten for ensuring I followed the appropriate procedures. Rebecca England for her assistance through the research process and Cathy Anumege for the difficult task of scheduling all the meetings and conferences with my committee.

I would also like to thank the Duval County School staff for their help. Principal Darrell Perry for encouraging me and allowing me to conduct the research at his school. Ruth Cox and Gerlieve Oliver for mentoring me as I started the principalship and reminding me that I must not neglect my family during the process. Nancy Snyder, Leila Mousa and Ed Pratt-Dannals for their understanding and support as my supervisors as I started the process. 


\section{TABLE OF CONTENTS}

Title Page

Certificate of Approval

Dedication iii

Acknowledgements iv

Table of Contents $\mathrm{V}$

List of Tables ix

List of Figures $\mathrm{X}$

Abstract of the Dissertation xi

Chapter I: Introduction 1

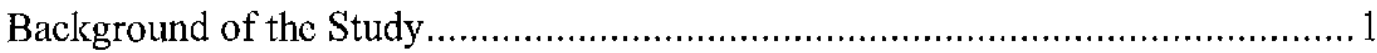

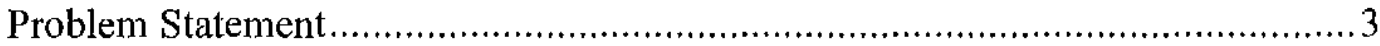

Professional Significance of the Problem ................................................... 4

Purpose of the Study and Research Questions .......................................... 5

Overview of Methodology .............................................................. 6

Research Context and Participants.............................................6 6

Instruments Uscd in Data Collection..........................................6 6

Intervention ................................................................................ 7

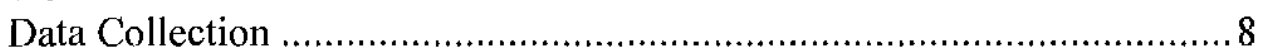

Data Analysis ..................................................................... 8

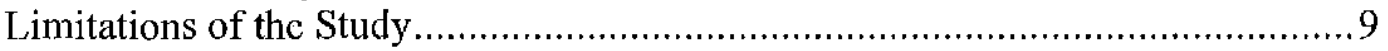

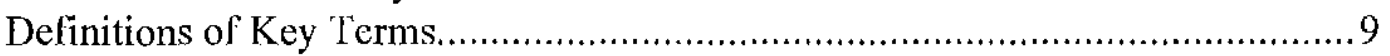

Organization of Dissertation ........................................................... 10

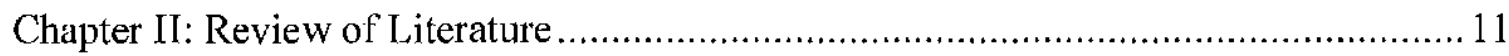

Search Process ............................................................................. 11

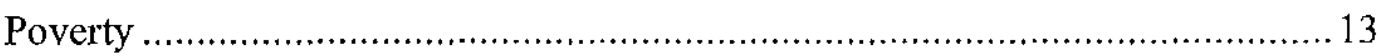

Impact of Poverty on Student Outcomes .......................................... 13 


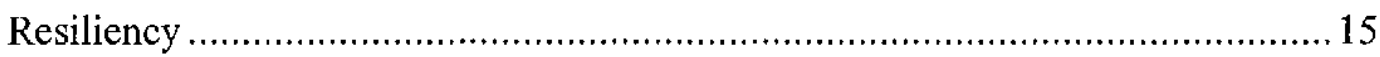

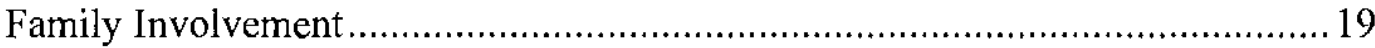

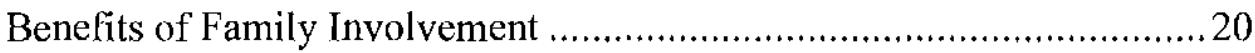

Family Involvement Program Development.........................................2.25

Involving Family Mcmbers in Program Development .................25

Subject-Specific Involvement Strategies ..................................26

Barriers to Family Involvement...............................................27

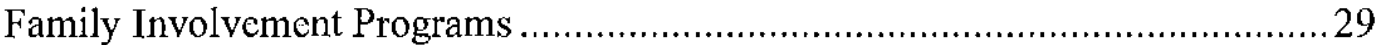

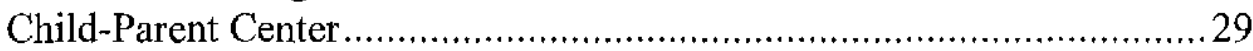

The National Network of Partnership Schools ........................................ 31

The Comer School Development Program .............................................. 33

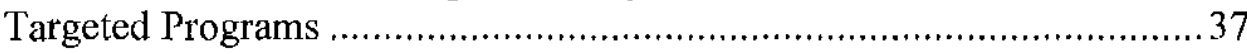

Framework for Understanding How Family Involvement Can Be Improved ......40

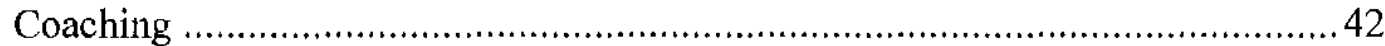

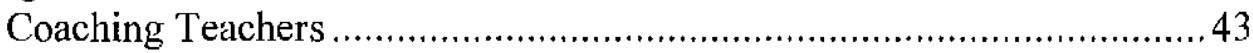

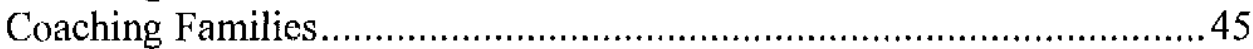

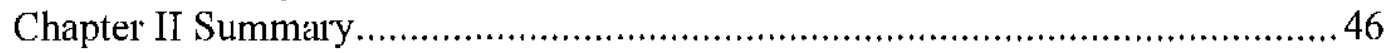

Chapter III: Intervention and Research Methodology .............................................. 49

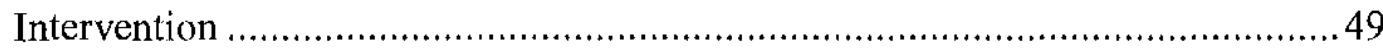

Family Involvement Theory of Action............................................... 49

Description of Intervention.............................................................. 50

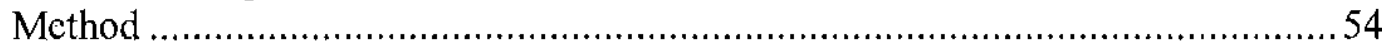

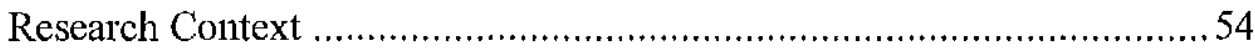

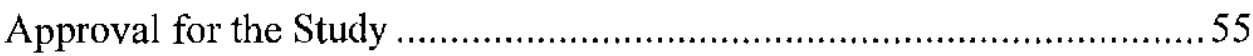

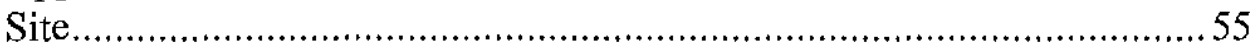

Recruitment of Families ..................................................................... 56

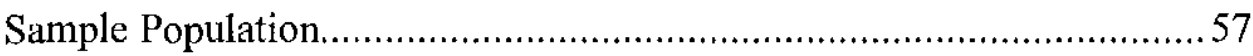

Instruments Used to Collect Data ......................................................58

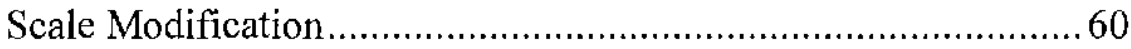

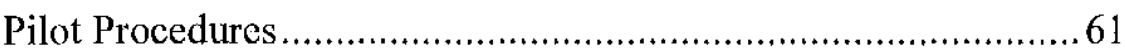

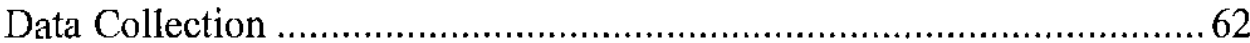

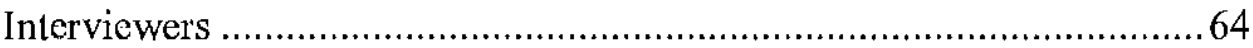

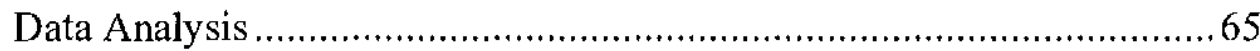

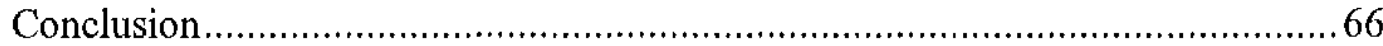

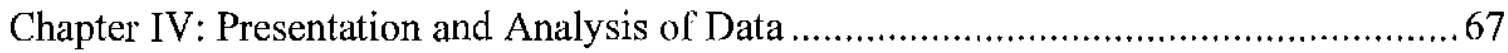

Income

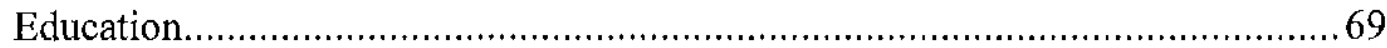

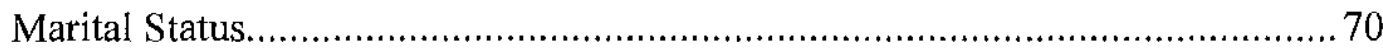

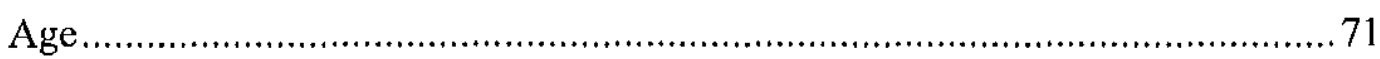

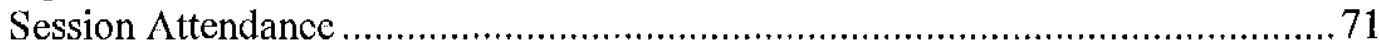

Pre-and Post-Intervention Mean Scores......................................................... 72

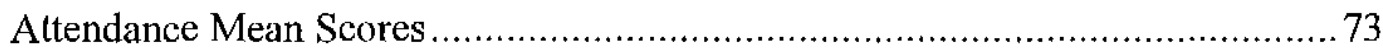


Relationship Between Attendance and Mean Scale Scores ................................ 74

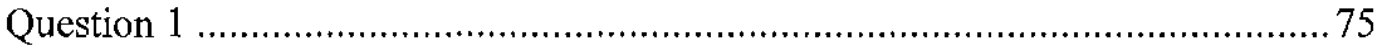

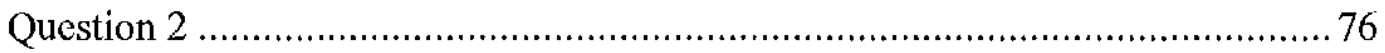

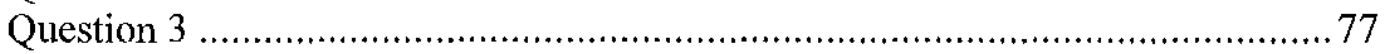

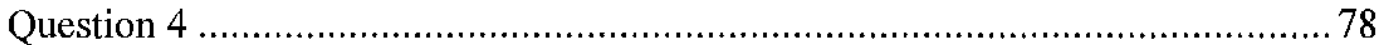

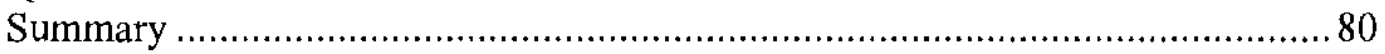

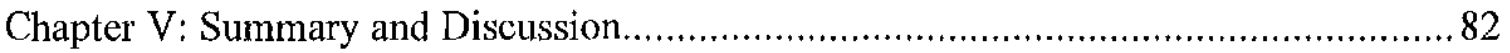

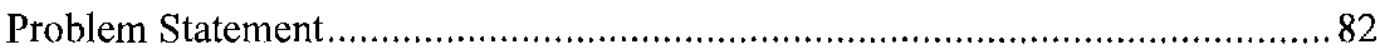

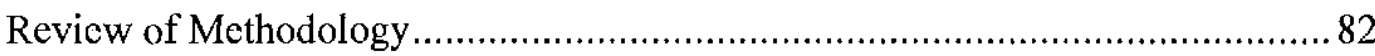

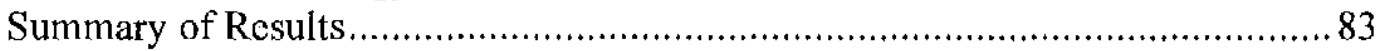

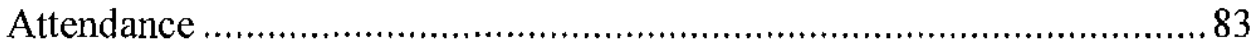

Parental Self-Efficacy, Encouragement, and Reinforcement Gains .........84

Family Involvement Learning Survey ............................................... 84

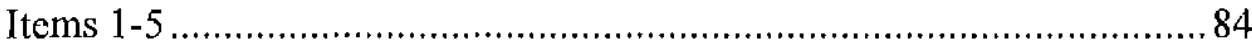

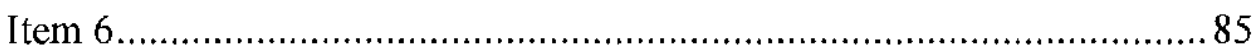

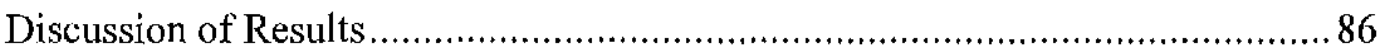

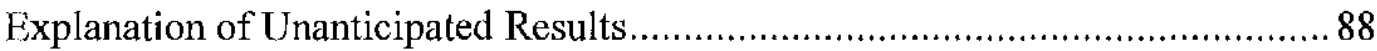

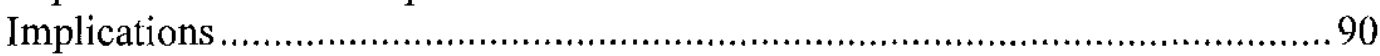

Recommendations for Further Research ....................................................99

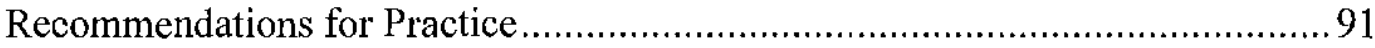

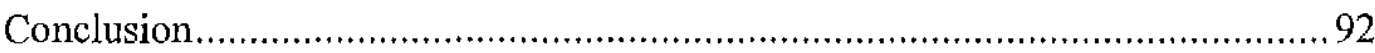

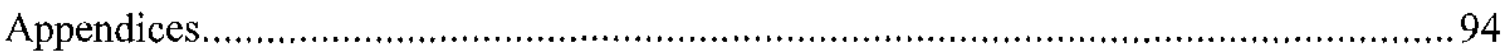

Appendix A: Family Coaching Institute Table of Specification........................95

Appendix B: Family Member Self-Reported Level Engagement ......................99

Appendix C: Institutional Review Board Letter of Approval......................... 101

Appendix D: Participants Informed Consent Form .......................................... 106

Appendix E: Participant Invitational Flyer................................................... 109

Appendix F: Participant's General Information Form ..................................111

Appendix G： FCI Schedule Preference Form ............................................ 113

Appendix H: Parental Self-Efficacy for Helping the Child

Succeed in School ..................................................................... 115

Appendix I: Parent Report of Encouragenent Scale .................................... 117

Appendix J: Parent Report of Reinforcement .............................................. 119

Appendix K: Family lnvolvement Learning Survey .................................... 121

Appendix L: Permission Granted to Modify Scales ..................................... 123

Appendix M: Modified Parental Self-Efficacy for Helping the

Child Succeed in School Scalc ................................................. 125

Appendix N: Modified Parent Report of Encouragement Scale ......................127

Appendix O: Modified Parent Report of Reinforcement.................................. 129 
References.

Vita 


\section{LIST OF TABLES}

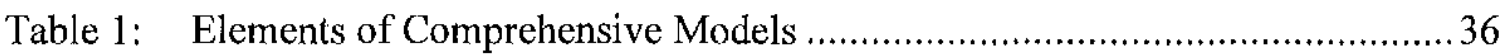

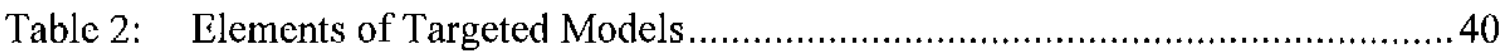

Table 3: Demographic Description of Sample Population ........................................5 58

Table 4: Internal Consistency of Data from the Original and Modified Scales

Cronbach's Alpha

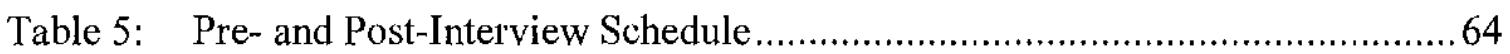

Table 6: Income Range of the Participating Family Members .................................69

Table 7: Education Level of the Participating Family Members ................................ 70

Table 8: Marital Status of the Participating Family Members ................................ 70

Table 9: Age Range of the Participating Family Members ..................................... 71

Table 10: Pre-and Post-Intervention Mean Scores .................................................... 73

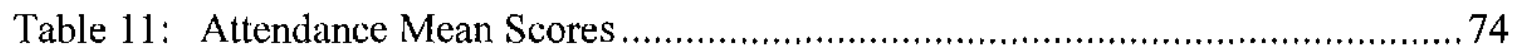

Table 12: The Modified Parental Self-Efficacy for Helping the Child Succeed in

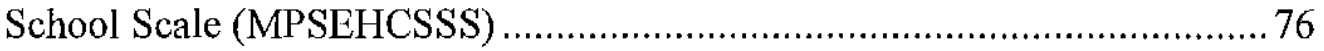

Table 13: The Modified Parent Report of Encouragement Scale (MPRES) ................. 77

Table 14: The Modified Parent Report of Reinforcement (MPRR) ............................ 78

Table 15: FIISS Item Means and Intervention Participants' Responses ........................79 


\section{LIST OF FIGURES}

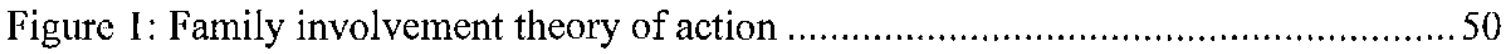

Figure 2: The range of the intervention participants' attendance ................................. 72

Figure 3: Reinforcement and encouragement attendance means ................................75 


\section{ABSTRACT OF THE DISSERTATION}

The purpose of this study was to assess the effects of participation in a family coaching program on perceptions of parental self-efficacy, families' use of encouragement, and reinforcement behaviors. A second purpose of the study was to ascertain the lasting cffect on families participating in a family involvement intervention that included coaching. Families with prekindergarten and/or kindergarten children attending school in a low-income neighborhood and neighboring child care centers werc recruited for the study.

The Family Coaching Institute, the family involvement intervention for this study, consisted of three 5-weck, 2-hour biweekly sessions. Attendance ranged from 3 to 15 sessions. Child care, dinner, learning activities, materials, books and supplies were provided. Participants were encouraged to use the activities at home with their children between sessions. Pre-intervention and post-intervention intervicws werc conducted with the participants using scales designed to measure parental self-efficacy, encouragement, and reinforcement behaviors. Family members also participated in a focus group and completed the Family Involvement Learning Survey 6 months after the intervention.

Results of the study indicated there were no statistically significant differences in responses from the beginning to the end of the intervention on the scales designed to measure parental self-efficacy, encouragement, and reinforcement behaviors. These findings are discussed in the context of a response shift bias. In contrast, ratings on the Family Involvement Learning Survey indicated participation in the intervention had a strong impact on family bchaviors. 
Chapter I: Introduction

\section{Background of the Study}

A major educational issue in the United States is the achievement gap between students from low-income families and students from more affluent families. Students from low-income families generally achieve at lower academic levels than their more affluent peers. When Florida began using the Florida Comprehensive Assessment Test to assess school performance in 1999, 78 schools were rated as failing and given a grade of F (Florida Department of Education, 1999). Of the 78 schools, 75 were located in lowincome neighborhoods where at least $70 \%$ of the students received free or reduced lunch. The schools ratcd as excellent had fewer than $50 \%$ of their students receiving free or reduced lunch (Florida Department of Education). The relationship between neighborhood income and the academic achievement of a school's students indicates that socioeconomic status (SES) has a significant impact on the school's success.

Narrowing this achievement gap continucs to be a central goal of educators, parents, local school boards and local, state, and national policy makers. Educators cannot, however, change the income level of families to improve students' achievement. In addressing this goal, educators have considered a number of different ways to bring about improved student achievement. 
Educators are using several initiatives to close the academic gap between students from low-income families and more affluent families. These initiatives include approaches such as lesson studies, charter schools, vouchers, and direct instruction.

The lesson study approach was developed in Japan. In the lesson study method, groups of teachers collaborate to develop effective lesson plans. The lesson is then taught by one of the teachers and observed by the others. After obscrving the targeted lesson, the teachers reconvene and revise the lesson to make it more effective. Only then is the lesson used across the school (Hicbert \& Stigler, 2000).

The charter school movement has recently become a popular method to improve achievement. Charter schools are private schools financed with public funds that may provide improved educational choices for students, parents, and teachers (Nathan, 2005). Charter school supporters advocate for site-based management, with decisions about budget, personnel, curriculum, and instruction made by people at the charter school site (Nathan).

Similarly, politicians and others suggest publicly funded school vouchers as another way to bring about improved achievement. Vouchers allow parents to choose their child's school if their local public school does not meet state academic standards. Under a school voucher system, families are given financial certificates, which can be used to pay tuition at the public, private, or parochial school of their choice (Nathan, 2005).

The direct instruction model is also believed to increase student achievement. The six steps of the direct instruction model are: (a) review previously learned material, (b) state objectives for the lesson, (c) present the new material, (d) provide corrective 
practice with corrective feedback, (c) assign independent practice with correctivc feedback, and (f) review both during and at the end of the lesson (Education Commission of the States, 1995). Data indicate the direet instruction model has been effective for increasing literacy in young children.

Another strategy used to raise the level of student achievement is to increase the level of family involvement. Several researchers have found that high levels of family involvement have positive outcomes, such as increased student achievcment, better attendance, better discipline and lower dropout rates (Comer \& Haynes, 1991; Epstein, 1995; Griffith, 1996; Henderson \& Berla, 1994). Increasing family involvement has become a national movement. In 1994, Congress added family involvement to Goals 2000 (Public Law 103.227, 1994). Several national programs such as the National Network of Partnership Schools (Epstein, Coates, Salinas, Sanders, \& Simon, 1997), the Chicago Child Parent Center (Reynolds, Temple, \& Miedel, 2002), and the Comer School Model (Comer \& Haynes) use family involvement as the foundation for their school improvement models.

\section{Problem Statement}

Schools in low-income and more affluent neighborhoods differ in several ways. A major difference is that schools in low-income neighborhoods tend to have less family involvement (Comer \& Haynes, 1991). As a strategy for increasing student achievement, educators have made efforts to incrcase the level of family involvement in schools in low-income neighborhoods. Some of the efforts have resulted in more family involvement; however, many families lack the necessary knowledge, skills, and resources to assist children with learning activities at home. 


\section{Professional Significance of the Problem}

Many students from low-income households are not ready to start school, and as a result they struggle throughout thcir school careers (Juel, 1988). It is essential that schools provide activities to help these students "catch up" with language, mathematics, and vocabulary skills. To do this, many schools adopt some type of family involvement program, and most of thesc programs give family members strategies to use but do not teach the parents how to use them.

Students from low-income families do not achieve at the same academic level as their more affluent peers (Crane, 1996; Desimone, 1999; Payne \& Biddle, 1999). Researchers have found that schools with a high level of family involvement have higher achievement than schools with low levels of family involvement (Crane; Griffith, 1996). Barriers for low-income families include a lack of resources, time, knowledge, and skills all of which lessen the amount of family involvement (Crane; Desimone; Payne \& Biddle). These same barriers have also been identified by cducation reformers as barriers to instructional improvement (Neufeld \& Roper, 2003).

One useful strategy used to overcome barriers that hinder involvement is coaching (Callahan, Rademacher, \& Hildreth, 1998; Colgan, 2002; Morrow \& Young, 1997). Some family involvement models have family coaching (Callahan et al.; Colgan; Morrow \& Young) to provide the training families need to improve their children's learning at home by increasing levels of knowledge and skills.

Family involvement programs may increase their effectiveness by considering why parents get involved (Hoover-Dempsey \& Sandler, 1995, 1997, 2005) and involving families in the program development process. According to Hoover-Dempsey and 
Sandler $(1995,1997,2005)$, parents get involved because of their beliefs in their selfefficacy and role construction. Therefore, this study investigated the cffects of family coaching in increasing parental self-efficacy as teachers of their children, levels of encouragement, and use of reinforcement to increase learning at home.

\section{Purpose of the Study and Research Questions}

The purpose of this study was twofold: to assess the extent to which the Family Coaching Institute (FCI) changed parental self-efficacy, the use of encouragement, and the use of reinforcement behaviors; and to ascertain if there were any lasting effects of the FCI intervention on participating family members. The study addressed four questions:

1. After controlling for the pre-intervention level of parental self-efficacy, is there a difference in the post-intervention measure of parental self-efficacy between families who participated in family coaching and comparison families who did not participate in family coaching?

2. After controlling for the pre-intervention level of parental encouragement, is there a difference in the post-intervention measure of parental encouragement between families who participated in family coaching and comparison families who did not participate in family coaching?

3. After controlling for the pre-intervention level of parental reinforcement, is there a difference in the post-intervention measure of parental reinforcement between families who participated in family coaching and comparison families who did not participate in family coaching? 
4. To what extent do families who participate in the Family Coaching Institute report on a survey collected 6 months after the intervention that participation led them to change their attitudes and behaviors about learning at home?

\section{Overview of Methodology}

\section{Research Context and Participants}

This study was part of 'The Family Coaching Institute (FCI) at Fernwood Elementary School (FES), a pseudonym for the actual school. The purpose of the program was to prepare young children to start school with the literacy skills necessary to become successful readers. The evaluation of FCI included assessing the impact of the intervention on parental self-efficacy, reinforcement, encouragement, and family involvement at home. The participants for this study were the family members of the kindergarten and prekindergarten children who attended FES and child care centers near FES. FES is an urban public school located in a low-income neighborhood in Northeast Florida.

\section{Instruments Used in Data Collection}

The instruments used in this study were based on instruments developed by Hoover-Dempsey and Sandler $(1995,1997,2005)$. The Modified Parental Self-Efficacy for Helping the Child Succeed in School Scale, the Modified Parent Report of Encouragement Scale and the Modified Parent Report of Reinforcement Scale are the modified scales. The original scales wcre developed for fourth- through eighth-grade students, and as a consequence had to be modified. The modified seales were pilot-tested 
to determine internal consistency. A post-intervention instrument (Family Involvement Learning Survey) was developed by the intervention facilitators to determine what impact the intervention had on participants' attitudes and behaviors 6 months after the intervention.

\section{Intervention}

The FCI consisted of three separate institutes composed of five, 2-hour biweekly coaching sessions. The intervention group completed Institutes I, II, and III and also completed a pre-intervention survey in the fall and a post-intervention survey in the spring. Family members were given the opportunity to choose which day of the week they participated. The schedule for each biweekly session included a 30-minute family conversation (life and home environment workshop), a 30-minute dinner and discussion period, and a 50-minute literacy coaching workshop, with a focus on the emergent literacy skills. Three intervention facilitators (family coach, family facilitator, and family liaison) planned and implemented the institutes. A family coach conducted the 50-minute literacy coaching workshop; the family facilitator conducted the 30-minute family conversation, the 30-minute dinner, and discussion period. The family liaison was responsible for coordinating child care, dinner, and assisting both the family coach and facilitator.

The first and second institutes followed the same format but offered different literacy topics and materials. The third institute differed only in that the family members assumed the roles of the intervention facilitators by leading the last two sessions of Institute III. 


\section{Data Collection}

An intervention and a comparison group were used for this study. The comparison group did not participate in the FCI but completed a pre-intervention interview in the fall and a post-intervention interview in the spring. Participants were interviewed using the modified scales at the beginning and end of FCI. Interviewers trained to use the modified scales were hired to interview study participants. Study participants received a stipend each time they completed an interview.

To determine if there were any lasting effects of FCI, participants were invited to attend a focus meeting after FCI concluded. At the meeting, participants completed a post-intervention survey designed to measure if $\mathrm{FCI}$ changed their attitudes and behaviors.

\section{Data Analysis}

Analysis of covariance (ANCOVA) was the statistical test used to determine whether family coaching influenced family self-efficacy, reinforcement, and encouragement. Because all study participants completed a pre-interventiont interview, an ANCOVA was used to control for any measured initial differences while increasing the power of the analysis. The null hypothesis that the adjusted mean outcome scores of the families participating in family coaching and the comparison families are not different was accepted if the probability that the scores represent a sample drawn from the hypothesized distribution of scores was greater than .05. All analytic procedures used two-tailed tests. Analysis of the Family Involvement Learning Survey involved summary statistics determined by the participant's responses. 


\section{Limitations of the Study}

This study had limitations. The findings of this study cannot be generalized

beyond FCl. First, the study did not have random assignment, and it was also limited by a small sample size which may indicate it is under-powered. The study was limited by the number of participants as well as the number of sessions of the intervention (15 sessions), and by the fact that modified scales were used.

\section{Definitions of Key Terms}

Family Involvement - The term family involvement will be used in this study instead of the term parent involvement because, according to Epstein (1995), a large percentage of students live with adults other than their parents. In this study, the term family involvement will be defined as family members' ability to assist their children at home academically, socially, and emotionally (Epstein).

Coaching - In this sludy, coaching refers to teaching family members the importance of their involvement by modeling effective academic strategies and behaviors, as well as allowing family members an opportunity to practicc these strategies, providing materials and supplies, and providing feedback and support.

Parental Self-Efficacy - This term refers to family members' beliefs about their ability to help their children with academic outcomes (Hoover-Dempsey \& Sandler, 1995, 1997, 2005).

Parental Encouragement - This term refers to family members' support of their child's participation in literacy activities (Hoover-Dempsey \& Sandler, 1995, 1997, 2005) 
Parental Reinforcement - This term is used to describe family members' acknowledgement of student behaviors in reference to academic outcomes (HooverDempsey \& Sandlcr).

\section{Organization of Dissertation}

Chapter I presents the background of the study. Included in this chapter are the problem statement and professional significance, followed by the purpose of the study and research questions. The methodology is reviewed along with limitations and definitions of key terms. Chapter II examines the literature related to the study. It begins with an overview of the processes used to locate literature relative to the study. Theoretical literature is then presented, followed by the empirical literature. Chapter III describes the theory of action, the intervention, the research context, the participants, and the procedures and methodology used in this study. Chapter III also explains instruments used to collect data, data collection procedures, and data analyses. Chapter IV presents the findings of the study, and Chapter $\mathrm{V}$ discusses the results. 


\section{Chapter II: Review of Literature}

This chapter is a review of the literature on family involvement, the relationship between income and school achievement, and the impact of family involvement on academic growth and performance. Several models of family involvement are reviewed, as is the research related to devcloping effective family involvement programs. This chapter concludes with a review of the research on coaching to build expertise and a summary.

\section{Search Process}

This review was developed using several search methods, including contacting researchers by phonc, e-mail, and through interviews. The first intervicw was with Dr. Craig Jones at the University of West Florida. We discussed his work and related research in the area of resiliency. Dr. Jones shared with me several resiliency references. I next contacted Dr. Joyce Epstcin, director of the National Network of Partnership Schools at Johns Hopkins University, to discuss her most recent work on family involvement and her perceptions of the missing gaps in family involvement research. During our discussion she shared her most recent research and discussed her use of the term family involvement instead of parent involvement. Dr. Epstein also discussed the differences in her six areas of family involvement and suggested the opcrational 
definition of family involvement used for this study. I met with Dr. Jon Supovitz in Jacksonville, Florida, in the fall of 2004. Dr. Supovitz conducted the research for the coaching component of the America's Choice school design. We discussed his findings, and areas for future coaching research. In addition, we discussed essentials of effective coaching such as training, modeling, and providing ongoing support and immediate feedback. In the summer of 2005, I visited Dr. Kathleen Hoover-Dempsey, director of the Peabody Family-School Partnership Lab at Vanderbilt University. During this visit I shared my proposed research and discussed Dr. Hoover-Dempsey's and her colleagues' research on family involvement. This body of work helped clarify insight into the importance of understanding how families construct their role as their children's first teacher and its influence on their involvement and ultimately on student outcomes. This understanding is embedded in the theory of action used in this study. Three of the instruments developed by Dr. Hoover-Dempsey and her colleagues were modified for use in this study.

The Social Science Citation Index and Education Resource Information Center were two sources used to identify theoretical literature and empirical research related to the topics used in this study. Several dissertations were reviewed to examine previous family involvement research and findings. Books were read to review the theoretical literature related to family involvement, poverty, resiliency, and coaching. Articles reporting both theoretical and empirical research were reviewed to identify the most current research related to these topics.

The revicw of current literature and interviews were used to develop Chapter II and the intervention for this study. 


\section{Poverty}

According to the United States Bureau of the Census (2000), there were 32 million people living in poverty in 1999. Of that group, $17 \%$ were children under 18 . According to Payne and Biddle (1999), this means that onc in every five children lives in low-income housing and lacks health care, healthy food, and adequate clothing. For those families in poverty, the average income in 1999 was $\$ 17,000$ for a family of four (United States Bureau of the Census). African Americans and Hispanics both have nearly one quarter of their ethnic groups in poverty, with $24 \%$ for African Americans and $23 \%$ for Hispanics. This compares to $8 \%$ of non-Hispanic whites who were in poverty in 1999 (United States Bureau of the Census). Harris and Wheeler (1997) described people in poverty as invisible because they lack so many resources.

\section{Impact of Poverty on Student Outcomes}

Poverty has a tremendous impact on the achievement of children in school districts across the nation. Researchers have found that students from low-income families do not perform as well academically as students from more advantaged families (Desimone, 1999; Epstein, 1995; Kozol, 1991). There is currently a push in educational policy to providc equal opportunities to all children regardless of income (Desimone). Epstein (1984) found that students from single-parent homes struggle, in part, because teachers have low expectations for these children. In addition, single-parent families are less likely to participate in school activities (Stevenson \& Baker, 1987). Brody and Flor (1998) found that low-income families are less educated, and research shows that less- 
educated families do not become involved in school at the same level as their welleducated counterparts.

Several studies have been conducted to determine the cffects of poverty on student academic outcomes. Crane (1996) determined that the level of socioeconomic status (SES) has a direct impact on student achievement. He set out to determine if SES had a positive or negative impact on the Peabody Individual Achievement Test (PIAT) in mathematics. The results indicated that students from the homes at the lowest income levels had the lowest scores on the PIAT. Desimone (1999) also conducted research to determine if there was a link between family income, student reading, and mathematics achievement. She used data from the National Education Longitudinal Study, which includes standardized test scores from 25,000 eighth graders. She examined the relationship between family attendance at PTO meetings and reading and mathematics achievement. For students from low-income families, there was no relationship between PTO participation and reading or mathematics achievement, but a positive relationship was found for students from middle-income families in reading and mathematics achievement. The study also found a positive relationship for students from middleincome families whose families volunteered at the school and increased reading and mathematics achicvement scores, whereas students from low-income familics whose families voluntecred at school did not show any significant increase in achievement.

Similarly, Gutman and McLoyd (2000) conducted a study of African American families living in poverty and the level of family involvement in the home. Data came from families in poverty that had at least one child attending one of seven elementary schools or one of four middle schools in a rural district. Their level of acadenic 
achievement was used to classify students; high-achieving students had at least a B+ GPA in fifth and sixth grades. Low-achieving students had a GPA no higher than D+ in fifth and sixth grades. The families of thc students were interviewed and asked a series of open-ended questions about their level of involvement. The results indicated that families of high-achieving students visited the schools often, involved their children in church and sports activities, and engaged in positive conversations with their children. Families of the low-achieving students visited the school only when they were asked to come because of their child's behavior or low grades and gave what the rescarchers classified as excuses to explain why they did not involve their children in extracurricular activities.

The research above reported inconsistent findings. Desimone (1999) found that there was no difference in academic outcomes of students from low-income families whose families participated in school activities and those whose families did not participate; however, she did find higher outcomes for students from middle-class families whose families participated in these activities. In contrast, Crane (1996) and Payne and Biddle (1999) both found that involvement of low-income families had a posilive impact on academic outcomes of students from low-income families.

\section{Resiliency}

Some students from low-income families perform academically as well as their more affluent peers (Huang \& Waxman, 1996). Recently, researchers have focused on the ability of students to succeed in low-income environments. According to HooverDempsey and Sandler (1995), some students succeed in school even if they live in lowincome homes where families do very little to promote their academic success. Benard 
(1993) defined a student's will to succeed in adverse conditions as resiliency, while Masten (1994) defined resiliency as a person's ability to adapt to tough situations. Berliner and Benard (1995) defined resiliency as a child's ability to become a productive citizen while fighting through adversity. Resiliency does not come about from any one thing but comes from the relationship between a child and his or her environments (Wang, Haertel, \& Walberg, 1997). According to Benard, resilient students are autonomous, have problem-solving skills, a sense of purpose, and are socially competent. Autonomy is the ability of a student to be an individual and separate himself or hersclf from the negative aspect of his or her low-income environment. Benard defined social competence as a student having good relationships with people and caring for others. She defined problem-solving skills as a student's ability to develop several solutions to a situation.

Research has shown that resilient students tend to have higher self-esteem than non-resilient students (Garmezy, 1994; Peng \& Lee, 1992). They see themselves as competent and able to learn, and as a result set high goals for themselves (Benard, 1991; Seligman, 1991). Resilient students have also been identified as having a strong internal locus of control (Benard; Garmezy; Peng \& Lee) and seeing themselves as having control over their own successes and failures. Resilient students have been identified as being actively engaged in their education and investing time and effort outside what is normally required of students (Benard; Wang et al., 1998). These students have also been described as having the strong interpersonal skills necessary for such interactions (Benard; Seligman). They are often characterized as adaptable; resilient students are open to new experiences and able to react appropriately when circumstances change (Wang et al.). 
They are able to distance themselves from negative conditions and make the best of positivc situations. Most importantly, resilient students have an adult who motivates and encourages them to be successful (Wang et al.).

Rescarchers have conducted studies to determine the differences between resilient and non-resilient students. Fluang and Waxman (1996) completed a study to determine differences between resilient and non-resilient Asian American students. They found resilient students were retained less often and expected to get a diploma, whereas the non-resilient students were retained more often and fewer believed they would graduate from high school. Rcsilient students also spent more time doing homcwork and skipped class less frequently than the non-resilient students. Huang and Waxman did not find a difference between the two groups in reference to TV watching, listening to music, or the level of family involvement. According to Huang and Waxmen, the students' level of efficacy and self-regulatory skills accounted for the differences in thcir levels of resiliency. Lee (1991) and her colleagues found that resilient students watched less TV than non-resilient students. Lee conducted a study to identify the difference in highachieving black males and low-achieving black males. The study revealed that the students from the higher-achicving group came from families with higher SES than the students of the low-achieving group. The higher achieving group read more, did more homework, and watched less television.

Bloir (1997) conducted a study on eharacteristics of the families of resilient students from low-income familics. Bloir found no differences between male and female students. However, he did find that students were closer to their mothers and that those with fathers had higher grades. The low-income families of the resilient students 
monitored their behavior, participated in decision-making, and communicated with them often. Most of the communication was with the mothers. Smokowski, Reynolds, and Bezruczko (1999) investigated resiliency in 86 students who participated in the Chicago Parent Center. For this study, resiliency was defined as at-risk students showing betterthan-average outcomes such as staying in school, performing close to grade level, and scoring well on standardized tests. The students were in $10^{\text {th }}$ grade and were interviewed about internal attributes, family ties, and external support systems. After the interviews, the students were asked to write an autobiographical essay. The essays revealed that the resilient students attributed their academic success to motivation and information from family members and teachers. The resilient students often reported that having family members and teachers as caring role models contributed to their success. Smokowski, Reynolds, and Bezruczko also found that strong predictors of the resilient students were the family's high academic expectations, early academic success in the lower grades, and high ratings from teachers.

The results of this section indicated that some students overcome their impoverished environments and succeed in school at or above the academic level of their peers from more advantaged families. Some of the research indicated that students' attributes such as goal-setting, high self-esteem, high self-efficacy, and a belief that they were in control of their success accounted for their resiliency. Other research indicated that resilient students had a caring adult in their lives. These students had an adult who monitored discipline, set high expectations and was supportive of their efforts to achieve. 


\section{Family Involvement}

Most of the research refers to involvement of adults with children's education as Parent involvement (Becher, 1984; Honderson, 1987; Olmsted, 1991). Epstein et al. (1997) used the term family involvement. According to Epstein, the term family involvement is more appropriate due to the fact that a large percentage of children live with adults other than their parents, such as grandparents, aunts, uncles, and other relatives. According to the resiliency research, an adult is extremely important to a child's success (Wang et al., 1998). Again, this person may not be the child's parent; it may be a coach, teacher, or any adult who is involved in the child's life.

The definitions used by Epstein et al. (1997) are widely used throughout the family involvement research. Epstein's framework includes six domains of involvement: parenting, communicating, volunteering, decision-making, collaboration with the community, and learning at home. These domains are described below.

Parenting - Providing clothing, safety, housing, and food (Epstein et al.).

Communication - The teachers sending home newsletters, memos, and report cards. They also stated that phone calls, conferences, and home visits are forms of communication and found that communication was corrclated with positive student outcomes (Epstein et al.).

Volunteering - Families assisting school staff and students at school fundraisers and at school functions such as sporting events, assemblies, and performances (Epstein et al.).

Decision-making - Families serving as active members of advisory councils, school improvement teams, and PTO/PTA momberships (Epstcin et al.). 
Collaboration with the community - The community provides business

partncrships, health services, recreation, and other type of services to the schools (Epstein et al.).

Learning at home - Family's ability to assist the child academically, socially, and emotionally at home (Epstein et al.).

A study by Entwisle and Alexander (1992) also found learning at home to be of great importance. These researchers conducted a study to determine if students from lowincome households losc or gain mathematics achievement over the summer. They compared the California Assessment Test mathematies scores of first graders (from highand low-income families) at the end of the school year and the start of their second-grade year. The researchers found that learning at home continued throughout the summer for the students from high-income familics, and little or no learning happened in the homes of the students from low-income families. The results showed an increase in the CAT mathematics scores of the students from high-income families and a decrease in the scores of the students from low-income families. The findings indicated that learning away from school has a significant impact on student outcomes.

\section{Benefits of Family Involvement}

Family involvement has been found to be an effective strategy for student improvement (Comer \& Haynes, 1991; Eccles \& Harold, 1996; Henderson \& Berla, 1994; Schefter, 2001; Stein \& Thorkidsen, 1999; Turner, 2000). According to Henderson and Berla, family involvement is the most important predictor of student academic outcomes. In a review of 50 articles, Stein and Thorkidsen found family involvement has 
a positive impact on sludent outcomes. Family involvement is effective for improving academic outcomes for students from preschool through high school (Alexander \& Entwisle, 1996; Eccles \& IIarold, 1993; Hart, 1998; Henderson, 1987) and is one of the eight goals in Goals 2000 (Public Law 103.227, 1994). Epstein (1995) indicated that students with involved familics are more likely to perform wcll academically in school than students who do not have involved families. Henderson and Berla's review of 66 studies of family involvement reported that students in schools where administrative staff made an effort to involve families had better grades, higher levels of attendance, higher graduation rates, more positive attitudes toward school, and fewer behavior problems than students in schools where staff did not promote family involvement.

Improving family involvement has become a local, state, and federal issue (Desimone, 1999). Desimone stated that schools cannot change factors like income, community, and family structure, but schools can have an impact on family involvement.

There are at least two ways to examine student outcomes. One method is student achievement, which cxamines student outcomes by posttest achicvement. Family involvement has been shown to be associated with increased student achievement (Epstein, Coates, Salinas, Sanders, \& Simon, 1997). Scholars seem to agree that a positive relationship exists between family involvement and academic achievement (Catsambis, 1998; Comer \& Haynes, 1991; Desimone, 1999; Henderson \& Berla, 1994).

High-achieving schools have a higher percentage of family involvement than lowachieving schools (Henderson \& Berla, 1994), and the students in these schools consistently score higher on standardized tests than students attending schools that lack family involvement (Comer, 1989). Epstein and Dauber (1991) suggested that students 
with high levels of family involvement have higher achievement and have teachers who communicate more with families when compared to students with low levels of family involvemcnt. A positive correlation has been found between student achievement and family involvement (Comer; Eccles \& Harold, 1993; Epstein \& Dauber; Griffith, 1996; Henderson, 1987; Hester, 1989).

In contrast, Horn and West (1992) and Milne (1986) found family involvement was associated with lower levels of student achievement. Crnic and Booth (1991) and Desimone (1999) found no relationship between family involvement and student achievement. However, McNeal (1999) suggested race and social class explain inconsistencies in the relationship between family involvement and student achievement.

A second evaluation method is student growth, which measures gains from pretest to posttest. Academic growth has been shown to increase with cffcctive family involvement (Becher, 1984; Henderson, 1987; Olmsted, 1991). According to Andcrson (2000), schools with a high level of family involvement referred fewer students for special education programs than schools with minimal involvement. Schools with high family involvement have students who are motivated about school and have families who have a more positive attitude about school (Becker \& Epstein, 1982; Comer \& Haynes, 1991; Epstein, 1986). According to Anderson, family involvement is needed throughout school to enhance children's cognitive growth and academic success. Epstein examined the effects of six types of family involvement and found that any form of family involvement helps student growth and achievement; however, learning at home had the greatest impact (Epstein, 1987). 
Several researchers have studied the impact of family involvement on academic growth. Keith (1993) used data from the National Education Longitudinal Study (Huang, Samcena, Peng, \& Owings, 1996) to examine the long-term effects of family involvement. The results indicated that the students with the highest level of family involvement demonstrated higher achicvement in most subject areas compared to the students with little family involvement. Griffith (1996) also studied the relationship between parent involvement and academic performance in a suburban school district. The families at the 41 schools in this study were given a 4-item survey composed of questions from regional and national surveys of school climate. Griffith's results indicated the schools with the highest level of family involvement had the highest scores on the criterion-referenced tests in reading and mathematics. In addition, Griffith found that the schools with the highest percentage of African American, Hispanic, and free or reduced lunch students scored much lower in family involvement and also scored lower on the criterion-referenced tests. In a similar study, Crane (1996) found a positive correlation between home environment and student academic growth. For this study, family involvement was associated with factors such as family income, level of familics' education, family structure, and household size. The results indicated that scores on the Peabody Individual Achicvement Test in mathematics were positively related to family involvement.

Clark (1989) completed a study to determine what type of family involvement positively affected student achievement. Clark used data from 1141 third graders who took the Comprehensive Test of Basic Skills (Form U). Surveys were sent to the families of the I 100 students who met the qualifications. The results indicated that the high- 
achieving students had families with a high sense of efficacy and ability to support their children.

The evidence from the empirical studies indicated that family involvement has a positive impact on student achievement and academic growth. A positive relationship was found to exist between family involvement and academic achicvement (Catsambis, 1998; Comer \& Haynes, 1991; Desimone, 1999; Henderson \& Berla, 1994). Several researchers also found that academic growth has been shown to increase with effective family involvement (Becher, 1984; Henderson, 1987; Olmstead, 1991).

Family involvement has several bencfits. Family involvement has been associated with lower drop-out rates (Epstein, 1992). Stronger family involvement has led to higher levels of homework completion, improving students' positive perception of school (Epstein), and increased teachers' expcctations of children, therefore increasing student outcomes such as improved behavior and achievement (Stevenson \& Baker, 1987). The greatest impact of family involvement is the positive impact on student achievement and academic growth (Henderson \& Berla, 1994). Several studies indicated that when families are involved in their child's education, the child will show improved academic outcomes (Comer \& Haynes, 1991; Henderson \& Berla). Schools have used family involvement to increase student achievement (Sheldon, 2002) and have given families strategies to increase involvement, usually in the form of newsletters, suggesting strategies at school events, or sending home activities for family members to use with the child (Epstcin, 1995). 


\section{Family Involvement Program Development}

The research conducted by Chen (2001) and Sheldon (2003) indicated a need for schools to develop effective family involvement programs. Under the No Child Left Behind Act, third- through eighth-grade students are required to take standardized tests (e.g., Florida Comprehensive Assessment Test), and the federal dollars must be used to implement research-supported family involvement programs. Family involvement programs are effective in improving student outcomes from preschool to high school (Chen). Effective programs increase student achievement as well as altendance (Hayes, Emmons, \& Woodruff, 1998). Fan and Chen (2001) concluded family involvement is positively influenced by effective family involvement programs; however, Mattingly, Prislin, McKenzie, Rodriguez, and Kayzar (2002) found family involvement programs had no influence on student achievement. Koonce and Harper (2005) recommended a partnership between community-based social services and school consultants. If schools are not proactive in involving families, many will not be involved (Sheldon). If families do not initiate family involvement, then the school should (Koonce \& Harper).

Involving family members in program development. Though several family involvement programs have been developed, they are most effective if schools tailor these programs to mcet the needs of their families. Programs are more effective if schools allow families to participate in the development of the program (Stein \& Thorkidsen, 1999). Berkowitz and Bier (2005) found that it is rare for families to be true partners during the development of school programs. To be effective, schools must move past traditional strategies when developing family involvement programs to increase achievement (Sheldon, 2003). According to Sheldon, young children will benefit when 
schools involve families in the learning process. According to Barrera and Warner (2006), the best family involvement programs allow time for open-ended and familydominated discussions, as well as providing home activities that require families and students to work together. Schools must conduct research to plan family involvement activities to increase student outcomes (Sheldon \& Epstein, 2003). Activities that include adult and child interactions at home are more likely to improve child outcomes (Sheldon \& Epstein). Hoover-Dempsey and Sandler (1995) contended that for students to have positive student outcomes, family involvement at home must be composed of ageappropriate strategies and activities, and the learning at home must also be in alignment with the school's expectations. The quality, not quantity, is the most important aspect of the activity (Sheldon \& Epstein). Collaboration between schools and families is essential to program effectiveness (Barrera, 2002; Henderson, 1987).

Subject-specific involvement strategies. Each of Epstein's six domains of family involvement leads to different student outcomes (Epstein, 1995). Some lead to higher achievement in areas such as mathematics and reading, while others lead to higher grade point averages, attendance, and homework completion. Subject-specific family involvement activities have positive effects on student outcomes (Epstein \& Sheldon, 2001; Sheldon \& Epstein, 2003; Simon 2000; Sheldon \& Van Voorhis, 2001). A subjectspecific program is a program that focuscs on only one subject such as reading, mathematics or one behavior such as homework completion (Epstein \& Sheldon; Sheldon \& Epstein, 2003; Simon; Sheldon Van Voorhis). Sheldon and Epstein (2003) conducted a study to determine which of the six domains had the greatest impact on mathematics achievement. The results indicated that schools that used a variety of learning-at-home 
strategies had more academic achievement in mathematics than schools that used strategies from the other five domains. Mathematics achicvement was detcrmined by growth on standardized exams.

Barriers to family involvement. Urban schools must consider the barriers that hinder the involvement of their low-income families. Even though family involvement has been shown to positively impact student outcomes, several barricrs hinder families from being involved in their children's education (Snith, 2001). Schools in low-income neighborhoods must address these barriers to improve sludent achievement (Sheldon, 2003). According to Koonce and Harper (2005), barriers to family involvement included poor school experiences, intimidation by school personnel, and inconvenient mecting times. Hoover-Dempsey and Sandler $(1995,1997)$ found that the lack of invitations from school personnel is another barrier. The research indicated that lack of resources, knowledge, skills, and time are the most prevalent barricrs that hinder family involvement, but schools can create opportunities for families to overcome these barriers (Hoover-Dempsey \& Sandler, 1995; Hoover-Dempsey et al., 2005).

Low-ineome families lack the resources to provide adequate materials and supplies needed to impact learning at home (Horvat, Weiniger, \& I,aureau, 2003). Shortage of resources such as transportation, child care, and income negatively impact the level of family involvement (Desimone, 1999; Hoover-Dempsey et al., 2005; Horvat, Weiniger, \& Laureau). Lack of knowledge and skills is a major barrier to family involvement (Hoover-Dempsey et al.; Smith, 2001). According to Kiley (1995), families involve themselves if they see a clear link between their involvement and their child's success. Schools provide little guidance for families to help at home (Shcldon, 2003). 
Many low-income families want to help but lack the know-how (Hoover-Dempsey et al.; Smith). This lack of knowledge and skills negatively impacts the academic performance of children from low-incomc families (Hoover-Dempsey et al.; Smith). Hoover-Dempsey et. al. found that families with a high perception of their knowledge and skills tended to be more engaged with their elementary-age children than families with a low perception of their knowledge and skills. Hamilies with low perceptions tended to allow others to assist the child or even have the child get assistance from teachers, friends, or other family members.

Time is the barrier most adults mention as the reason for their lack of involvement (Carey, Lewis, \& Farris, 1998; Leitch \& Tangri, 1988; Smith, 2001; U.S. Deptartment of Education, 1994; Yap \& Enoki, 1994). Some researchers have found the lack of time is the greatest barrier (Carey et al.; Kiley, 1995). Working families, working mothers, and scheduling problems are some of the reasons families indicated that hinder their involvement (Laureau, 1989; Muller \& Kerbow, 1993; Smith). Families with multiple jobs, set schedules, and high-demand jobs are involved less than families with flexible schedules, low-demand jobs, or part-time jobs (Hoover-Dempsey et al.) regardless of income.

Family involvement programs can improve student outcomes (Hayes, Emmons, \& Woodruff, 1998), and they are mandated for low SES schools that receive federal funding. These programs are more effective if schools allow families to bccome involved in the development of the program (Stein \& Thorkidsen, 1999). Programs can also bc more effective if they have a single academic focus, such as mathematics only (Epstein \& Sheldon, 2001, 2002). Schools should also address the barriers that hinder family 
involvement when developing program barriers such as lack of knowledge, skills, resources, and time (Kiley, 1995; Hoover-Dempsey et al., 2005).

The next section provides a description of effective family involvement programs that have implemented research-based strategies. Some are comprehensive in that they impact the entire school and take at least 3 years for full implementation. The targeted programs focus on a particular class or grade level and are initiated and completed in less than a year. Both the comprehensive and targeted programs were developed using strategies identified in the literature as effective in increasing family involvement.

\section{Family Involvement Programs}

Varying definitions for family involvement have led to the development of several different approaches. All programs, however, are designed to foster greater family engagement and result in improved student outcomes (Eccles \& Harold, 1996). Several researchers have developed frameworks or models for family involvement and have developed programs derived from them. Three of the most effective comprehensive family involvement programs are the Child-Parent Center, the National Network of Partnership Schools, and the Comer School Model.

\section{Child-Parent Center}

The Child-Parent Center (CPC) is a school-based program for preschool through third-grade students that provides ongoing family support services (Reynolds et al., 2002). The program was designed for students from low-income families and has a mandatory family involvement component. The curriculum of the $\mathrm{CPC}$ focuses on basic 
literacy skills and social development. The CPC involves families along with teachers in their children's education (Reynolds et al., 2002). Families are required to spend at least a half-day per month at the school, and each school has a head teacher who coordinates the program, a school/community resource person, at least one parent resource teacher and a parent room (Reynolds et al.). Students are usually involved in the program from 3 to 6 years (Reynolds et al.). The program is designed to accommodate the families' daily schedule by offering the program throughout the day. Families are given training, feedback, and the necessary materials and supplies as well as information on health, nutrition, safety, and consumer issues.

Reynolds et al. (2000) assessed the effectiveness of the program as part of the Chicago Longitudinal Study. Students taking part in the CPC for 4 years had higher rates of graduation, higher test scores, fewer placements in special education, and lower rates of abuse, neglect, violent behavior, and delinquent behavior than students who wcre not involved in the program or who were involved less than 4 years. Reynolds et al. also found that there were economic benefits of the program. Tax dollars were not needed to support long-term participating students through welfare or for educational remediation.

Reynolds, Temple, Robertson, and Mann (2001), using a sample from Reynolds' original study, sought to determine the long-term effects of program participation. Data came from school records, court records and surveys. Participants in the CPC program were the experimental group, and kindergarten students who did not altend preschool were the comparison group. The results of the study were similar to the original study (Reynolds et. al, 2000). Students involved in the program from 3 to 6 years had lower rates of special education placement, arrest records, and child abuse than students in the 
program from 1 to 3 years and students in the comparison group. Students involved in the program from 3 to 6 years had higher rates of high school completion and student achievement than students in the program from 1 to 3 years and sludents in the comparison group. One-to-threc-year participants had higher rates of high school completion and student achievement than the comparison group in the same areas.

\section{The National Network of Partnership Schools}

Joyce Epstein developed The National Network of Partncrship Schools (NNSP). This program established strong partnerships among schools, communities, and families, and the Center on School, Family, and Community Partnerships at Johns Hopkins University. The program involved students from prekindergarten through twelfth grade, and took 3 years to fully implement.

Each participating school had an action team charged with focusing on one or more of Epstein's areas of family involvement. The team was led by a full-time project facilitator and consisted of familics, administrators, teachers, and counselors. The team initially used the school's improvement plan to begin developing a plan of action. Each member of the action team was responsible for one of six committees. Each committec was responsible for assessing partncrships, writing plans for improvement, and improving one of Epstein's six types of family involvement.

Sanders (2001) conducted a study to determine the effectiveness of the NNPS on increasing community partnership activities. All NNSP schools were asked to complete a survey called UPDATE to update the current school information and discuss the effectiveness of the partnership. At lcast $70 \%$ of the schools reported at lcast one 
community partncrship activity. Some schools reported as many as five. These partnerships included some Fortune 500 companies, but the majority of the participants were local businesses. Sanders found that lcvels of collaboration with the community had increased in the participating schools.

In another study of the NNSP, Epstein and Dauber (1991) studied family involvement programs in inner-city schools. Data came from 171 teachers at eight randomly selected middle and elementary schools in Baltimore. The data from all the schools summarizing the effectiveness or ineffectiveness of Epstein's six domains on impacting family involvement programs were combined and given to each school to develop projects to improve their family involvement programs. Each school used the data to develop its action plan, and $\$ 1000$ was given to the directing teacher to evaluate the school's plan. The results indicated that the majority of tcachers had a positive attitude in reference to family involvement, and those in sclf-contained classrooms had a more positive attitude about family involvement than teachers who taught only one subject. The more positive teachers' attiludes towards family involvement, the more they incorporated family involvement practices in their classrooms. The implications of this sludy suggest that using assessment data to develop action plans was an effective strategy to improve teachers' attitudes towards family involvement and increase family involvcment practices in the classroom.

In summary, the NNSP was designed to increase the effectiveness of family involvement throughout the entire school community by focusing on Epstcin's six areas of family involvement. Data from several studies suggested the NNSP strategies are 
effective in increasing involvement of low-income families in their children's school experience.

\section{The Comer School Development Program}

James Comer developed the Comer School Development Program (SDP) while working with two struggling New Haven inner-city schools. The mission of the SDP was to increase academic and social development for children living in low-income familics by creating educational environments that support their physical, cognitive, psychological, language, social, and ethical development (Malloy \& Rayle, 2000). The SDP improved school climate, provided training to families and school staffs, and improved the curriculum. The SDP worked with faculty, staff and families to establish high expectations and improve family involvement through decision-making and volunteering.

The framework of the SDP consists of nine elements: three mechanisms, thrce guiding principles, and three operations. Three teams compromise the SDP mechanisms:

- $\quad$ The School Planning and Management Team (SPMT) includes administrators, families, staff, and teachers and is usually led by the principal. The primary objective of the SPMT is to develop and monitor a plan to facilitate professional development goals, school morale, and academic achievement (Malloy \& Rayle, 2000).

- The Student and Staff Support Team includes guidance counselors, nurses, a speech pathologist and a school psychologist. The primary function of this team is crisis prevention (Malloy \& Rayle). 
- The third team, the Parent Team, is composed of families and community members. The purpose of the Parent Team is to establish a relationship between the families and the school. Families participate in traditional activities such as PTA, volunteer in the school, and serve on the elected School Planning and Management Team (Malloy \& Rayle).

The three SDP teams use the guiding principles of consensus, collaboration, and no-fault (Malloy \& Rayle, 2000). The three elements comprising operations are a comprehensive school plan, staff development, and assessment and modifications. Comcr's framework also recognizes the importance of communication, volunteering and decision-making (Comer \& Haynes, 1991).

Several studies indicated that schools implementing the Comer Model effectively demonstrated increases in student achievement and school outcomes. Comer and Haynes (1991) studied one New Haven school that implemented their program. The school adopted the program to help families become more aware of services for children offered by the community. The School Planning and Management team established a Share Night. During this event, community service providers informed families about the services they offered. The results of the Share Night were so successful that it became an annual school event.

Malloy and Rayle (2000) completed a study to determine the effectiveness of the SDP on an ineffective middle school. The middle school chosen for the study was an inner-city school with African American students. The school was known for its violence, high turnover of principals (four in 3 years), low morale, and poor family involvement. The new principal implemented the Comer School Model. Within 3 years the number of 
violent acts decreased, as did the number of students receiving referrals. The percentage of non-black students increased as did the overall achievement levels of the students. Participation of minority families in school activities increased, and the PTA elected its first minority parent as president.

In 1993, San Diego State University conducted a 5-year study to determine the effectiveness of the program on reading and mathematics achievement (Council of the Great City Schools, 1995). Data were collected from more than 5000 students at Comer Schools, and five non-Comer schools were used as the comparison group. More than 300 teachers and 1000 families were surveyed. Families and teachers of thc Comer schools rated their schools' climate higher than the teachers and families of the non-Comer schools rated the elimate of their schools. The results showed a positive relationship existed between increased student achievement and parent and teacher attitudes about the school's climate. High family and teacher ratings of school climate were associated with high student achievement in reading and mathematics.

Cook et al. (1999) conducted a study to determine the effectiveness of the Comer School Model in 23 middle schools. The study took 4 years to complete and was conducted in schools with less than 2 years of implementation of the SDP. The results of the study indicated that Comer Schools with at least some implementation of the program showed more improvement in social and psychological conditions than schools that had no SDP implementation.

In summary, the Comer School Model was designed to create a positive school environment where families and teachers work together to help develop the students and place strong emphasis on changing the school climate. Students, staff, and families are 
expected to participate in the program for at least 3 years (Comer \& Haynes, 1999). Buyin from the principal and the staff is essential for effective implementation (Comer \& IIaynes). The focus of the SDP is on child devclopment, human development, and relationship-building betwcen schools and families. Families provide a link between home and school. They also volunteer, assist in classrooms, and participate in decisionmaking.

Elements that are shared by all three models are depictcd in Table 1.

Table 1

Elements of Comprehensive Models

\begin{tabular}{lcccccc}
\hline Framework & $\begin{array}{c}\text { Commun- } \\
\text { ication }\end{array}$ & Volunteering & $\begin{array}{c}\text { Decision- } \\
\text { making }\end{array}$ & $\begin{array}{c}\text { Learning } \\
\text { at home }\end{array}$ & Parenting & $\begin{array}{c}\text { Collaborating } \\
\text { with community }\end{array}$ \\
\hline SDP & $\mathrm{X}$ & $\mathrm{X}$ & $\mathrm{X}$ & $\mathrm{X}$ & $\mathrm{X}$ & $\mathrm{X}$ \\
NNSP & $\mathrm{X}$ & $\mathrm{X}$ & $\mathrm{X}$ & & & $\mathrm{X}$ \\
CPC & $\mathrm{X}$ & $\mathrm{X}$ & $\mathrm{X}$ & $\mathrm{X}$ & $\mathrm{X}$ & $\mathrm{X}$ \\
\hline
\end{tabular}

All three models are designed to impact the entire school, improve family involvement, and increase student achievement, and all three take at least 3 years for full implementation. Epstein's NNSP model strcsses partnerships, uses the term family instead of parent, can be uscd with elementary, middle, and high schools, and uses the school's current school improvement plan. The CPC model is designed only for elementary schools, has a family outreach program, and provides health and social services. The SDP altempts to develop the whole child, provides staff development, and focuses on curriculum and instructional development. The SDP also makes a strong effort to improve school climate. 


\section{Targeted Programs}

Not all family involvement models are comprehensive models. Several targeted models have been developed to increase student achievement and family involvement (Callahan, Rademacher, \& Hildreth, 1998; Colgan 2002; Jordan, Snow, \& Porche, 2000; Morrow \& Young, 1997). There are several differences between the comprehensive and targeted models. Unlike the comprehensive models, the targeted models can take fewer than 9 weeks for full implementation, and there is little or no focus on school climate or social services. The targeted models typically are developed for a class or grade level instead of the cntire school and families are often provided resources to improve learning at home.

Colgan (2002) conducted a study of a targeted family involvement designed to improve reading achievement. Students from one grade levcl in an elementary school were given a pretest. Families who participated came to the school for coaching. There were six sessions, and each lasted about 2 hours. At the lirst session, the coach explained the purpose of the program and the expected results. The coach read selected books and modcled effective literacy activities to provide an example for the families and students. At the session, children participated in literacy activities with families. Books were provided for families and students to take home. Each book came with a book report workshect that was to be completed by the parent and child and returned to the next meeting. Families and students completed one activity per book (for example, stick puppets, circle story, mini-book, paper bag puppet, word search, or flap booklet). Each activity included skills integrated across the curriculum. The coach provided materials and supplies such as construction paper, writing paper, pens, crayons, markers, scissors, 
and glue. Progress was reported on wall charts, and students took a posttest at the end of the six sessions. Results indicated that students whose families participated in the program and completed all the activities scored higher on the posttest than students whose families did not parlicipate or only completed a few activities.

Callahan et al. (1998) conducted a 10-week program which included two coaching sessions, each lasting about 2 hours. At the first meeting, the study was explained in detail and the families completed questionnaires. The coach then gave a 30minute presentation about the importance of homework. The coach used role-playing to demonstrate how to use the materials and complete the assignments. Families then demonstrated the role-play. Families were given all homework materials and a stipend to purchase incentives to reward student effort. The outcome of the study resulted in approximately $80 \%$ of the participating students demonstrating an increase in the number of assignments completed and an increase in the overall quality of their work.

Morrow and Young (1997) developed a program with two components designed to increase learning at home. The first program component was school-based, with teachers using several strategies to increase reading achievement and student motivation. The comparison group only received the school program. The second component of the study was the family program. Students and families in the experimental group received the family program as well as the school program. Participating families received coaching and materials such as notebooks, index cards, storyboards, and Highlights magazines that could be used at home. Demonstrations were given on the effective use of the materials. Families were asked to record completed activitics which they shared at group meetings. Between meetings the coach contacted families and provided support 
and encouragement to families. At the second meeting, children told the group what they did at home. Post-intervention interviews were conducted with teachers, students, and families. The results indicated students in the experimental group scored higher on the Probed Recall Comprehension test, and their teachers rated them higher in reading and writing performance and interest than the comparison group. The two groups did not differ on the California Test of Basic Skills.

Jordon et al. (2000) developed the Early Success in Education Project. Participating families attended an evening meeting where the study was explained in detail, including the rescarch principles behind the study. The comparison families gave permission for their children to be tested without receiving the intervention. Families were given a guide with all the information about the sessions. The coach trained families once a month for 5 months. At the end of each meeting, families were given the opportunity to engage the child in and practice the desired interaction strategies. The families completed projects in school with the child and at home. During the following 3 weeks the classroom teacher sent homc scripted activities based on the monthly training. Follow-up trainings were held during the school day as well as in the mornings and evenings to accommodate parent schedules. Altendance records were kept, and families completed evaluation sheets for each activity sent homc. The results indicated that children whose families participated in the program had more growth in retelling stories, vocabulary, and comprehension than students whose families did not participate.

Elements that the targeted models share are depicted in Table 2. All models provide coaching and modeled activitics. Most of the models included children in the 
sessions and provided materials and supplies. The Callahan study (1998) provided a stipend, and the Morrow and Young (1997) model provided support between sessions.

Table 2

Elements of Targeted Models

\begin{tabular}{lcccccc}
\hline \multicolumn{1}{c}{ Study } & $\begin{array}{c}\text { Coaching } \\
\text { provided }\end{array}$ & $\begin{array}{c}\text { Materials and } \\
\text { supplies } \\
\text { provided }\end{array}$ & $\begin{array}{c}\text { Support } \\
\text { betwcen } \\
\text { sessions }\end{array}$ & $\begin{array}{c}\text { Stipends } \\
\text { provided }\end{array}$ & $\begin{array}{c}\text { Involved } \\
\text { the child in } \\
\text { session }\end{array}$ & $\begin{array}{c}\text { Coach } \\
\text { modeled } \\
\text { activities }\end{array}$ \\
\hline $\begin{array}{l}\text { Colgan, } \\
2002\end{array}$ & $\mathrm{X}$ & $\mathrm{X}$ & & & $\mathrm{X}$ & $\mathrm{X}$ \\
$\begin{array}{l}\text { Callahan, } \\
1998\end{array}$ & $\mathrm{X}$ & $\mathrm{X}$ & $\mathrm{X}$ & $\mathrm{X}$ \\
$\begin{array}{l}\text { Morrow } \\
\text { and Young, }\end{array}$ & $\mathrm{X}$ & $\mathrm{X}$ & $\mathrm{X}$ & & $\mathrm{X}$ & $\mathrm{X}$ \\
$\begin{array}{l}1997 \\
\text { Jordan et } \\
\text { al, 2000 }\end{array}$ & $\mathrm{X}$ & & & $\mathrm{X}$ & $\mathrm{X}$ \\
\hline
\end{tabular}

Both comprehensive and targeted models have effective attributes.

Comprehensive models have school-wide impact. The targeted models had immediate results and impacted very fewer students. All the models provided some form of coaching and modeling to families and attempted to overcome barriers that hinder family involveinent.

Framework for Understanding How Family Involvement Can Be Improved

Schools have attempted to increase family involvement to improve student outcomes and have met with limited success (Hoover-Dempsey \& Sandler, 2002). According to Hoover-Dempsey and Sandler, in order for schools to effectively involve families, they must understand why families get involved, types of activities in which 
families are most likely to participate, and how these activities might impact student outcomes.

Hoover-Dempsey and Sandler's (1995) model was developed from theoretical rescarch in educational, developmental, and social psychology. The purpose of the model was to explain the process of family involvement. Four findings emerged. First, families got involved because they felt it was a part of being a parent. Second, families chose to become involved bccause they believed they had the skills and knowledge to help their child achieve in school (personal sense of efficacy). Third, familics got involved simply because their children and schools invited them. Finally, when families got involved their children observed them modeling teacher-like behaviors, the children were reinforced for engaging in school behaviors, and their motivation for school and learning increased in ways that resulted in better student achicvement.

Hoover-Dempsey and Sandler (2005) recently completed a 3-year project designed to test the attributes of their earlier model of family involvement $(1995,1997)$ and to dcvelop and establish validity and rcliability data for instruments used to measure the constructs: role construction, self-efficacy, encouragement, and reinforcement. The project explored reasons why families chose to participate in their child's education and the results of their involvement. All of the survey instruments yielded reliable and valid data for each of the constructs. The instruments were tested with hundreds of family members. The instruments were refined and retested with over 800 participants to establish reliability estimates.

The results indicated that families get involved as a result of their motivational bcliefs about their role construction and self-cfficacy, their perceptions of invitations 
from school staff and children, and their perceived life context of their knowledge, skills, time, and energy. The results also indicated that when families are involved they provide modeling, encouragement, reinforcement, and instruction at home.

\section{Coaching}

The research indicated that lack of knowledge and skills are barriers to family involvement (Kiley, 1995). This is in part due to the fact that schools do very little to teach families how to impact lcarning at home (Shcldon, 2003). Neufeld and Roper (2003) stated that coaching in a school helps instructional staff as well as leadership. According to Neufeld and Roper, coaching is defined as providing professional development to school staff to develop the knowledge of the entirc school. Teachers develop or improve instructional strategies, and principals are coached in areas such as the effective use of data to drive instruction and maximum use of the school budget. According to Thompson and Ross (2000), coaching is derived from mentoring, but coaching does not take as long to become effective. Thompson and Ross also recognized that coaches are skilled and can teach thcir skills to others by demonstrating, observing, and providing fcedback. In Thompson and Ross's study, coaches werc used in prekindergarten, kindergarten, and first-grade classrooms. The coaches provided professional development to the classroom teachers, modeled lessons, observed the teachers' instruction, and met with the teachers throughout the year. The year-long coaching intervention yielded positive results. Student achievement was assessed with fall pretests and spring posttests using the Test of Early Reading Ability and an inventory measuring alphabet letter recognition. The results of both assessments indicated a statistically significant increase on the spring assessments. 
The literature on coaching has identified several aspects of coaching that are associated with teacher effectiveness. Ross (1992) used workshops conducted over the course of a year along with face-to-face and telephone coaching. Donovan's 1992 study allowed for a coach to be placed in the school full-time, teachers and administrators were trained in coaching, teachers were given opportunitics to coach each other (collegial coaching), the coach accepted the views of the coachee, and feedback was given by the coach.

\section{Coaching Teachers}

According to Neufeld and Roper (2003), coaches help teachers beeome better at delivcring instruction in a certain area like reading, mathematics, science, or discipline. Coaches help teachers transfer knowledge from workshops into the classroom (Neufeld \& Roper). Coaches also help teachcrs develop lesson plans, leadership skills, and communication skills (Neufeld \& Roper). According to Neufeld and Roper, for coaching to bc effective, coaches must have skills and knowledge and support from school-based and district administrators.

Ross (1992) conducted a study to determine if eoaching history teachers had an impact on student achievement. Eighteen teachers were assigned a history coach. The students in their classes werc given a prctest in Scptember and a posttest in May to determine changes in academic growth. The teachers were given the new curriculum and attended three, half-day workshops throughout the year. In reference to coaching, some was done over the phone and some face to face. No limit was given to how many times the teachers and coach would meet or who would initiate this contact. The results of the 
study indicated that the teachers who reported the most contact with their coach had students who achicved at higher levels on the posttest.

Donovan (1992) completed a longitudinal study that also indicated coaching had a positive impact on student achievement. Teachers were coached for 4 years. The study used several types of coaching which were implemented throughout the 4-year study:

1. Collegial groups met to provide support and share strategies;

2. The coaches observed and coached the teachers and met with them at least 3 times within 2 months;

3. All the teachers in the study were trained in coaching and were given time to observe each other and provide feedback to cach other;

4. Coaches were eventually assigned to each school in the study, facilitated collegial meetings, demonstrated lessons, and provided professional development; and

5. Administrators were trained in the coaching model.

Student achievement was determined by student scores on standardized tests. The teachers taught grades 4 to 12 . The first year, very little difference was noted in student achievement. At the end of the study, elementary students had gains in mathematies, middle school students had gains in both reading and mathematics, and high school students showed a drop in reading and gains in mathematics. According to the researchers, the drop in high school reading may have been the result of reading not being taught in English classes. 


\section{Coaching Families}

A few studies have indicated that when families are coached on how to help their children with academics, their children do belter than children whose families do not receive coaching. Colgan (2002) completed a study that included the coaching of families. For 6 weeks Colgan hosted a reading club for families. She invited families to join the club to be coached about how to help their children at home with reading. At the six meetings Colgan demonstrated several literacy activities to the families for use at home. She read books aloud, pointing out effective reading attributes such as voice, rhythm, articulation, and fluency. Colgan also demonstrated craft activities, book sharing, author's chair, and singing. At the end of each session, the families selected a book and completed the assigned projects at home. The families completed a pre-session questionnaire at the start of the project and a post-session questionnaire at the end of the 6 wecks. The results showed that families who attended and completed the program were more likely to complete the projects at home.

In a similar study, Callahan et al. (1998) conducted research on the impact of coaching on homework completion and quality. Families were given the opportunity to participate in a homework study program. The families participated in two, 90-minute training sessions which provided strategies and materials family members could use to help their children complete homework assignments. Prior to the study and before the families were trained, the students' rate of homework completion and homework accuracy was collccted. During the 10-week study, the families helped with homework and the students returned the assignments to their teacher who graded and logged the work. Dala indicated that students whose families implemented the strategies had a 
higher rate of homework turn-in and answered more of the homework questions correctly than the students whose families only completed some of the strategics or were not coached.

\section{Chapter II Summary}

This review revealed that students from low-income homes often do not perform as well in school as their more affluent peers (Desimone, 1999; Epstein, 1995; Gutman \& McLoyd, 2000; Kozol, 1991). Even though many students from low-income homes struggle in school, some are performing well (Bloir, 1997; Lee, 1991). This ability to overcome adversity is known as resiliency (Smokowski et al., 1999). For many of these children, there is an adult in the child's life who provides guidance, support, and encouragement (Wang et al., 1997).

When family involvement is associated with resilient children, there can be a positive impact on student outcomes (Benard, 1993; Epstein et al., 1997). Family involvement has been shown to be associated with increased academic growth (Bccher, 1984, Henderson, 1987; Olmsted, 1991) and achievement (Catsambis, 1998; Comer \& Haynes, 1991; Desimone, 1999; Epstein et al.; Henderson \& Berla, 1994). Schools throughout the nation have used a variety of programs to increase family involvement and student outcomes. Scveral programs have had success promoting family involvement and student achievement by harnessing family guidance and support. Comprehensive programs such as the Comer School Model (Cook et al., 1999; Malloy \& Rayle, 2000), the National Network for Partnership Schools (Epstein \& Dauber 1991; Sanders, 2001), and the Child Parent Centers (Reynolds et al., 2000) have been successful in total school 
reform and take at least 3 years for full implementation. Targeted models of family involvement impact a few classes or a grade level, have a single focus, and are often short in duration. Both comprehensive and targeted models used coaching as a strategy to increase the knowledge and skills families necd to improve learning at homc, which can lead to positive student outcomes.

If schools are to successfully involve families by developing effective family involvement programs, school officials should consider what factors influence why families choose to get involved, what they do once they are involved, and how these activities impact student outcomes (Hoover-Dempsey \& Sandler, 1995, 1997, 2005). According to Hoover-Dempsey \& Sandler, families' perceptions will influence family behaviors. These perceptions will influence student proximal and distal outcomes.

Family involvement programs can improve student outcomes (Hayes et al., 1998) and are mandated in low SES schools that receive federal funding. These programs are more effective if schools allow families to become involved in the development of the program (Stein \& Thorkisden, 1999). Programs can also be more effective if they have a single academic focus (Epstein \& Sheldon, 2001, 2002). When developing family involvement programs, school officials should address the barriers that hinder family involvement, such as lack of knowledge, skills, resources, and time (Kiley, 1995; Hoover-Dempsey et al., 2005).

Educators can use coaching to reduce barriers to family involvement (Kiley, 1995). Coaching tcachers has been used as a strategy to improve student achievement (Neufeld \& Roper, 2003). Children with family members who have participated in family involvement programs with coaching have increased thcir achicvement (Colgan, 2002). 
Chapter II presented the theoretical and empirical research associated with this study. These findings were uscd as design parameters for the intervention described in Chapter III. Chapter III describes the theory of action, the research context, participants, procedures, and methodology used in this study. Chapter III also explains the instruments used to collect data, data collection procedures, and how the data were analyzed. 
Chapter III: Intervention and Research Methodology

The purpose of this study was to examine the impact of family coaching on family attitudes (parental efficacy, encouragement, and reinforcement) and behaviors. This study also examined whether or not the intervention had an impact on family members' attitudes and behaviors 6 months after the intervention. Chapter III presents the theory of action and gives a description of the intervention. Chapter III also describes the methodology used in this study, including a description of the research context, project planning, instruments used, scale modification, data collcction procedures, and data analysis.

\section{Intervention}

\section{Family Involvement Theory of Action}

The premise for the thcory of action (Figure 1), derived from the rescarch, posits that students' academic outcomes are influenced by their families' involvement in their learning and that the family involvement will be influenced by family coaching. To influence student outcomes, the Family Coaching Institute was designed to increase parental self-cfficacy; incrcase understanding of caregivers' rolc as a teacher; and overcome the lack of resources, knowledge, and skills; and increase levels of encouragement and reinforcement provided to children. The Family Coaching Institute 
(FCI) taught and modeled academic rituals and routines designed to influence family members' altitudes and behaviors.

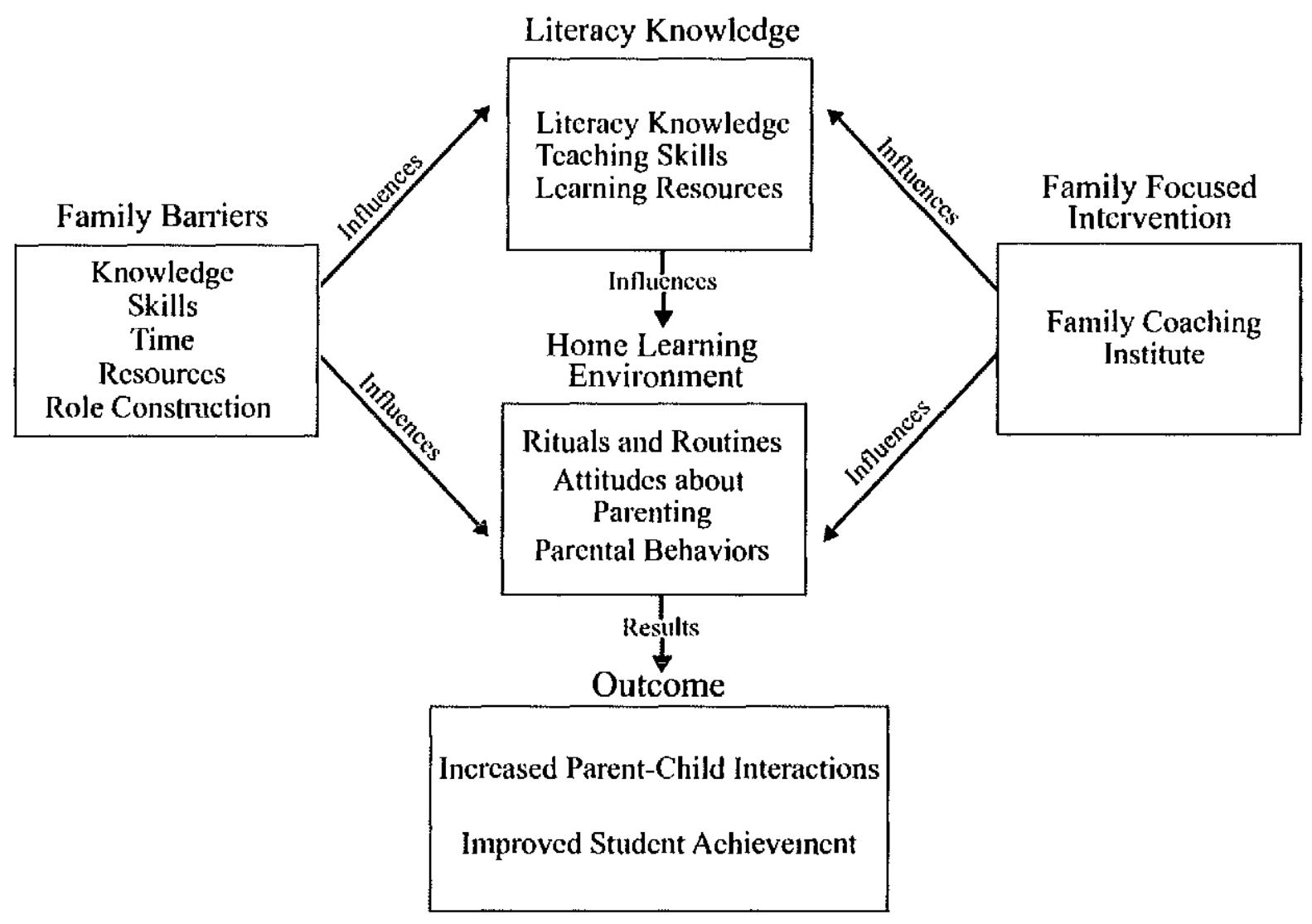

Figure 1. Family involvement theory of action.

\section{Description of Intervention}

The FCI intervention consisted of three separate but interrelated institutes, Institutes I, II, and III. (Appendix A). Each institute consisted of five, 2-hour biwcekly coaching sessions at Fernwood Elementary School (FES). The schedule for each biweekly session included a 30-minute family conversation (life and home environment workshop), a 30-minute dinner and discussion period, and a 50-minute literacy coaching workshop, with a focus on the emergent literacy skills of reading aloud, oral language, 
letters and sounds, phonological awareness, and print concepts and emergent writing. Three intervention facilitators (family coach, family facilitator, and family liaison) planned and implemented the institutes. A family coach conducted the 50-minute literacy coaching workshop, the family facilitator conducted the 30-minutc family conversation and the 30-minute dinner and discussion period. The family liaison was responsible for coordinating child care, dinner, and assisting both the family coach and facilitator. The family liaison also contacted each family between sessions to answer questions, give additional support, and monitor completion of activities. When parents arrived for the workshop, thcy signed in, put on their name tags, and completed the Family Member Self-Reported Level Engagement survey documenting the activities completed during the 3 weeks between the sessions (Appendix B).

Each family life and home environment workshop began with a 10-minute introductory activity which served the dual purpose of introducing the topic for the session and engaging participants in a way that did not penalize late-arriving participants. The remainder of the family workshop time was devoted to a participant-centered activity on a topic related to family relationships, family life, or the home environment. During the second 30-minute period of the session, family members relocated to another room for dinner and discussion. During dinner the family coach facilitated a discussion of the topies covered during the earlier period; a highlight of the discussions involved family members' personal reflections on the topic.

After the dinner discussion period, the families returned to the original room for the literacy portion of the session. Each session participant received a family literacy bag containing three books, descriptions and instructions for activities, and the supplies and 
materials the family would need to complete the literacy activities at home. The family coach modeled the activities to be implemented at home, discussed the content of the literacy bags, and demonstrated ways family members could use the supplies and materials in teaching their children and completing the activities. During the final 15minute period, the children joincd the adult members of their families to practice the modelcd activity. During the adult/child practice period, the intervention facilitators circulated to provide additional support and encouragement.

As the session drew to a close, a drawing for prizes was held for participants who arrived on time to encourage participants to be punctual. Participants also received attendance points to be redeemed at the cnd of each institute for gift cards and tickets to local attractions designed to encourage family conversations. Examples included trips to the local zoo, plays, children's theme parks, and the local museum to engage family interactions in learning places.

Institutes I and II wcre designed to build skills in working on literacy-related activities with children and help families establish learning-related rituals and routines. The focus of Institute III differed firom Institutes I and II. As with Institutes I and II, Institute III consisted of five sessions, but the focus was preparing family mombers to be leaders of literacy sessions as a strategy to increase their self-efficacy and to empower them to become literacy leaders in the communily. During the first, second, and third sessions of Institute III, the intervention facilitators worked with the family members to develop the skills needed to conduct the last two sessions. Participants learned to communicate effectively, lead discussions with their peers, and model literacy activities. Family members learned how to set up for the sessions, transition from one activity to 
anothcr, set up dinner, and explain family literacy bag contents. Family members were also given the opportunity to choose activities from Institutes I and II that would be the focus of their planned session.

As family members were engaged in their wcekly session, their targeted 4- and 5year-old children and their siblings (ages 2 through 12 years old) were engaged in Children's Club (CC). CC was an educational child care service of the FCI. The CC was led by a certified teacher and experienced teacher assistants with an adult ratio of one adult to 10 children. During $\mathrm{CC}$, the children were divided into two groups based on their age levels so that the activities they experienced would be developmentally appropriate. During $\mathrm{CC}$, children were engaged in hands-on interactive learning activities related to what their family members were learning doing their session. Children in the $\mathrm{CC}$ were also served a well-balanced meal.

The curriculum of the $\mathrm{CC}$ was tied directly to the curriculum of the family literacy bags as well as the adult FCI sessions. The $\mathrm{CC}$ was designed so that children were having experiences similar to their adult family members for discussions after the sessions in their homes. During the final 15-minutes of the FCI weekly session, the targeted children went to the room with their family members to practice the modeled literacy activity together. 


\section{Method}

\section{Research Context}

This study was conducted in the fall and spring of 2005-2006 as part of the FCI at the Fernwood Elementary School. The goal of the study was to test the impact and feasibility of a family coaching model designed to reduce the barriers identified by scholars as hindrances to meaningful involvement of low-income families in their children's education. Barriers include perception of the role of families in their children's education and the lack of role construction, lack of resources, knowledge, skills, and time. Ovcrcoming the barricrs results in increased family involvement in the education of their preschool and kindergarten-age children (Hoover-Dempsey et al., 2005; Sheldon, 2003; Smith, 2001).

The purpose of this study was to assess the extent to which participation in the FCI project impacted selected family attitudes and behaviors related to student achievement found to be associated with high achievement and family involvement. The FCI sought to influence participants' perceptions of their role in their children's education, their ability (knowledge and skills) to influence their children's school success, the necessary time to be meaningfully involved in activitics related to their children's educational outcomes, and the availability of the resources needed for active involvement. Variables included in the study were cach family's use of reinforcement and encouragement practices to motivate their child to engage in activities and behaviors associated with school success. To ascertain if there were lasting effects of the FCI intervention, participating family members were invited to attend a focus group meeting 
6 months after the intervention. At the meeting, the family members were given a postintervention survey to assess any long-term effects of the intervention.

\section{Approval for the Study}

The directors of the project obtaincd permission and cooperation from several child care providers, the school district, and Fernwood Elementary School (FES) to conduct the study. The project measured several areas of family involvement, and I requested permission from the director of the project to include three additional surveys to measure parental efficacy, encouragement, and reinforcement.

I completed the University of North Florida's Institutional Review Board (IRB) application. The IRB application was submitted to the project director, who approved and added this information to the official application which was submitted to the IRB (see Appendix C). Approval for the project was received October 4, 2005.

Study participants signed an informed consent form at one of several informational meetings (see Appendix D) where the need for consent was explained. Participants were also informed about their rights, told that participation was on a volunteer basis, and that they could withdraw from the study anytime. Participants were assured of confidentiality and told how the results would be used.

Site

FES served as the site for the FCI project. FES is an urban public school nestled in a low-income urban community in northeast Florida. FES serves students from prekindergarten through the fifth grade. At the time of the intervention, the school had 
600 students; $99 \%$ of the students were African American and $95 \%$ received free or reduced lunch. The mobility rate for the school was close to $40 \%$ each year. The state of Florida annually rates schools based on students' achievement on reading, writing, and mathematics examinations. High-achieving schools receive A or B grades, averageachieving schools receive $\mathrm{C}$ grades, and low-achieving schools receive $\mathrm{D}$ or $\mathrm{F}$ grades. FES received a D grade for 6 consecutive years (1999-2005). In the 2005-2006 academic year, FES received a $\mathrm{C}$ grade.

\section{Recruitment of Families}

The family coach met with child care center directors in the FES neighborhood, presented the program to them, and solicited their support. Directors were asked to encourage families to participate in the program. Child care directors were also invited to serve on the Advisory Board of the Fernwood Elementary School Family Involvement and Early Learning Community project. A multifaceted approach was used to recruit participants:

- Distribution of flyers announcing the project. At the end of the day, flyers wcre given directly to family members when their child was picked up or flyers were sent home in the children's backpack when direct contact was not possible.

- Invitations to information sessions. 'The invitation was distributed to all potential participants (see Appendix E). The information session included dinner, child care and door prizes. 
- Telephone calls. Invitations, information and reminder calls were made to inform families of mectings, program components, program schedules and start dates, and to encourage attendance and participation.

- Reminders. Wristband bracelets were given to the children on the day of the information session with time and location information.

At the informational session, an overview of the program, the purpose of the study, and the expected outcomes were explained. Program components including dinner, child care, and door prizes were described. Family members choosing to participatc in the study wcre asked to:

- complete a Demographic Information Form giving basic demographic information (see Appendix F),

- sign an informed consent form allowing their child to be assessed and agreed to participate in the 1-hour, face-to-face interviews (see Appendix D),

- complete a participants' Preference Form indicating their preference and availability for times and days of the week (see Appendix G).

The comparison group consisted of family members who completed informed consent forms and were not able to participatc because of time conflicts, or who chose not to participate in the intcrvention.

\section{Sample Population}

The participants for this study included 38 family members with children enrolled at FES and 7 child care providers located within the FES neighborhood. The 38 families were divided into two groups. The first group was the comparison group. The comparison 
group consisted of individuals who chose not to participate in the intervention $(n=25)$.

The second group, the intervention group $(n=13)$, started the intervention at FES in October.

Table 3 contains demographic information about the participants. All of the participants (intervention and comparison) were female. At least $70 \%$ of the participants for both groups were employed. Thirty-eight percent of the intervention group lived in the target zip code, and $68 \%$ of the comparison group lived in the target zip code arca.

Table 3

Demographic Description of Participating Families

\begin{tabular}{llcccc}
\hline \multirow{2}{*}{ Demographic } & \multicolumn{2}{c}{ Level } & \multicolumn{2}{c}{ Intervention } & \multicolumn{2}{c}{ Comparison } \\
\cline { 3 - 6 } & & Number & Percent & Number & Percent \\
\hline Gender & Female & 13 & $100 \%$ & 22 & $88 \%$ \\
& Male & & & 3 & $12 \%$ \\
Employed & Yes & 10 & $77 \%$ & 18 & $72 \%$ \\
& No & 3 & $23 \%$ & 7 & $28 \%$ \\
\multirow{3}{*}{ Zip Code } & Target Zip Code & 5 & $38 \%$ & 17 & $68 \%$ \\
& Other Zip Codes & 8 & $62 \%$ & 8 & $32 \%$ \\
Race & African American & 10 & $77 \%$ & 25 & $100 \%$ \\
& Other & 3 & $23 \%$ & & \\
\hline
\end{tabular}

\section{Instruments Used to Collect Data}

Four instruments were used in this study. Hoover-Dempsey and Sandler (1995) designed of the instruments used to mcasurc encouragement, reinforcement, and parental cfficacy. Hoover-Dempsey and Sandler report measures of internal consistency for scores on each scale (see Table 4). These three instruments were modified because they were developed for families with children in grades 4 through 8 (scale modification is discussed later in this chapter). I designed the fourth instrument to measure the impact of 
the intervention on family mombers' behavior and attitudes 6 months after the intervention took place.

Parcntal self-eflicacy was defined by Hoover-Dempsey and Sandler as "parents" belief in their ability to have a positive impact on their child's outcomes" $(2005, \mathrm{p} .15)$. The instrument, the Parental Self-Efficacy for Helping the Child Succeed in School Scalc (PSEIICSSS), consists of 7 survey items (Appendix H). The items assess parents' beliefs about their ability to assist with their children's academic outcomes. The PSEHCSSS scalc includes items such as, "I feel successful about my cfforts to help [CHILD] learn," and "I make a significant difference in [CIILLD]'s school performance." Response options for this scale are 1(disagree very strongly), 2 (disagree), 3 (disagree just a little), 4 (agree just a little), 5 (agree), 6 (agree very strongly). Data resulting from the use of the scale indicated an estimated internal consistency, Cronbach's Alpha, of .78 (HooverDempsey \& Sandler, 2005).

Parental encouragement is defined by Hoover-Dempsey and Sandler (2005) as "family members' positive support of their children in reference to school work" (p. 15). The instrument, the Parent Report of Encouragement Scale (PRES), consists of 13 survey items (Appendix I). This scale is used to assess parents' affective support of their children's relationship with school. The PRES includes items such as, "I encourage [CHIILD] to believe that he/she can do well in school," and "I encourage [CHILD] to stick with problems until he/she solves it." Response options for this scale are 1 (not at all true), 2 (a little bit true), 3 (somcwhat true), 4 (often true), 5 (mostly true), 6 (completely true). Data resulting from the use of the scale indicated an estimated internal consistcncy, Cronbach's Alpha, of 92. 
Parental reinforcement was defined by Hoover-Dempsey and Sandler (2005) as "families letting children know they are happy when the children exhibit positive behaviors in refcrence to school work" (p. 15). This instrument, the Parent Report of Reinforcement (PRR), consists of 13 survey items (Appendix J). It includes items such as, "We show [CHILD] we like it when he or she wants to lcarn new things," and "Wc show [CHILD] we likc it when he or she tries to learn as much as possible." Response options for this scale are 1 (not at all true), 2 (a little bit true), 3 (somewhat true), 4 (often true), 5 (mostly true), 6 (completely truc). Data resulting from the use of the scale indicated an estimated internal consistency, Cronbach's Alpha, of .96. Each scale is groundcd in related literature and has been tested for clarity and content in earlier studies, which indicates the content validity of the scales.

I developed the Family Involvement Learning Survey (FILS), which consists of 6 survey itcms (Appendix K). It includes items such as, "Participation in the Family Involvement Literacy Program increased my confidence in my ability to help my child learn at home," and "Participation in the Family Involvement Literacy Program has led me to turn everyday experiences into learning opportunities for my child." Response options for this survey range from 1 (strongly disagree) to 10 (strongly agree). This instrument also included one open-ended item.

Scale modification. The Parental Self-Efficacy for Helping the Child Succeed in School Scale (PSEHCSSS), the Parents Report of Encouragement Scale (PRE), and the Parents' Report of Reinforcement (PRR) were developed for use with parents of children enrolled in grades 4 through 8 , and as a result some of the items were not appropriate for 
parents of prekindergarten and kindergarten children. I contacted the developer of the instruments and requested permission to modify the scales to make them appropriate for use with the study population (Appendix L). Permission was granted to modify the scales as long as the pilot work was done to ensure the reliability of data resulting from the use of modified instruments. All three instruments were modified and pilot-tested with parents of prekindergarten and kindergarten children. The modified instruments are titled the Modified Parental Self-Efficacy for Helping the Child Succeed in School Scale (MPSEHCSSS), the Modified Parent Report of Encouragement Scale (MPRES), and the Modified Parent Report of Reinforcement (MPRR).

Pilot procedures. I contacted two child care providers (not part of the study) to request permission to pilot the modified instruments. I also met with the directors of Thunderbolt Preschool (TP) and Sunset Preschool (SP), both pseudonyms for the actual child care center names, explained the study, and the need to pilot-test the instruments. The family members of TP were predominantly urban, low-income and African American; the families of SP wcre predominately suburban middle class and Caucasian $\Lambda$ mericans. These two sites were selected for the pilot study to account for racial and income bias. Permission was granted to administer the scales to the parents of the prekindergarten students at the annual open house at SP and at a family night at TP. The SP scales were administered to one group $(n=20)$ at open house, and the next day the scales were also given to parents not in attendance $(n=30)$. The parents were asked to return the scales to the child care director (response rate $=10$ ). The TP scales were 
administered to the parents $(n=20)$ at the family night. The data from the modified scales were analyzed to estimate a measure of internal consistency (Table 4).

The resulting data for the MPSEHCSSS (Appendix M) were found to have Cronbach's Alpha of .89, the MPRRS (Appendix N) .98, and the MPRES (Appendix O) .98.

Table 4

Internal Consistency of Data from the Original and Modified Scales: Cronbach's Alpha

\begin{tabular}{lccc}
\hline Scale & PSEHCSSS* & PRES** & PRR *** $^{* *}$ \\
\hline Original Scalc & .78 & .92 & .96 \\
Modified Scales & .89 & .98 & .98 \\
\hline * Parental Self-Efficacy for helping the Child Succeed in School Scale \\
** Parent Report of Encouragement Scale \\
*** Parent Report of Reinforcement
\end{tabular}

\section{Data Collection}

The of families who did not participatc in the intervention were administered the modified surveys at the start of the intervention in the fall and at the end of the intervention in the spring of the school year. The intervention group was interviewed approximately 3 weeks into Institute $I$ as a result of recruiting difficulties with the interviewers. The intervention group was interviewed a second time at the end of the intervention.

The survey responses were collected in face-to-face interviews to ensurc the return of the surveys and to control for variation in reading ability. Interviewers also ensured that each participant responded to cach survcy item. A stipend was given to participants each time they were interviewed. To determine the extent to which there 
were lasting intervention effects, family members of the intervention group were invited to a focus group meeting in January, 6 months after the intervention. The purpose of the meeting was to administer the Family Involvement Learning Survey (Appendix K).

The MPSEHCSSS, MPRES, and MPRR were used to answer the following three questions:

1. After controlling for the pre-intervention level of parental self-efficacy, is there a difference in the post-intervention measure of parental self-efficacy between families who participated in family coaching and comparison families who did not participate in family coaching?

2. After controlling for the pre-intervention level of parental encouragement, is there a difference in the post-intervention measure of parental encouragement between families who participated in family coaching and comparison families who did not participate in family coaching?

3. After controlling for the pre-intervention level of parental reinforcement, is there a difference in the post-intervention measure of parental reinforcement between families who participated in family coaching and comparison families who did not participate in family coaching?

The FILS was administered at a focus group meeting 6 months after the intervention to answer the following:

To what extent do families who participate in the Family Coaching Institute report on a survey collected six months after the intervention that participation led them to change their attitudes and behaviors about learning at home? 
The comparison group was administered the MPSEHCSES, MPRES, and the MPRR from November through April; however, $86 \%$ took the survey by February. Both the comparison and intervention groups were administered the post-intervention survey in May and June (see Table 5).

Table 5

Pre- and Post-Intervention Interview Schedule

\begin{tabular}{ccccccccc}
\hline \multirow{2}{*}{ Group } & \multicolumn{4}{c}{ Pre-Intervention } & \multicolumn{3}{c}{ Post-Intervention } \\
\cline { 2 - 9 } & Nov & Dec & Jan & Feb & Mar & Apr & May & June \\
\hline Intervention & 3 & 10 & & & & & 5 & 8 \\
Comparison & 1 & 15 & 1 & 8 & 2 & 1 & 10 & 15 \\
\hline
\end{tabular}

\section{Interviewers}

Intervicwers completed two 3-hour training sessions that wcre conducted by the FCI directors. Interviewers were paid a stipend to attend the training and they also received compensation for each family member they interviewed. The interviewers' training consisted of reviewing background information of the study and the purpose of the surveys. The actual surveys were reviewed item by item. Each item was read and discussed. The interviewers were then given instructions about how to administer the surveys, ethical concerns, time limits and how to contact parents. At the second training session, interviewers practiced administering the survey to each other. After the interviewers correctly administered the survey, they were given contact information for family members. The interviewers contacted the family members and scheduled appointments at a place of the family member's choice. Some chose their homes, and some chose FES. Each interview took approximately 1 hour to administer. 


\section{Data Analysis}

SAS Version 9.1 was used for data analysis. Analysis of covariance (ANCOVA) was used to measure the impact the intervention had on parental self-efficacy, encouragement, and reinforcement. Participants were administered pre- and postintervention interviews. ANCOVA models were used to detect any post-intervention differences in the parental self-efficacy measure, MPSEHCSES, between the participating and comparison families and to control for any pre-intervention differences on the MPSEHCSES measure. ANCOVA models were used to detect any postintervention differences in the parental encouragement measure, MPRES, between the participating and comparison families and to control for any pre-intervention differences on the MPRES measure. ANCOVA models were used to detect any post-intervention differenccs in the parental reinforccment measure, MPRR, between the participating and comparison families and to control for any pre-intervention differences on the MPRR measure. The null hypothesis that the adjusted mean post-intervention scores of the families participating in family coaching and the comparison families are not different was accepted if the probability that the scores represent a sample drawn from the hypothesized distribution of scores was greater than .05. All analytic procedures used two-tailed tests.

The extent to which participating families reported, on a survey collected 6 months after the completion of the Family Coaching Institute, that their participation led them to change their attitudes and behaviors about learning at home was determined by inspection of the distribution of the item responses. 


\section{Conclusion}

Chapter III presented the procedures and methodology used to study the impact of family coaching on parent's self-efficacy, encouragement, and reinforcement and the impact of the intervention on the families who participated in family coaching group 6 months after the intervention. The theory of action, intervention, the sample population, and the procedures used were described, as were the instruments used to collect data. Data to support the validity and reliability of scores on the instruments were reported. Results of a pilot study to establish validity and reliability for scores on a modified form of the instruments were provided. Finally, a description of the data analytic procedures used to address the study's research questions was provided. 
Chapter IV: Presentation and Analysis of Data

The purpose of this study was to investigate the relationship between family coaching and family bchaviors and attitudes toward learning at home. The behaviors measured were encouragement and reinforcement and the measured attitude was parental self-efficacy. The effect of family coaching on the participants measured 6 months after the intervention was also investigated.

Data were collected three timcs during the study. Prc-intervention data were collected from the intervention group in November and December 2005. Pre-intervention intervicw data for the comparison group were collected November 2005 through April 2006. Post-intervention interview data were collected in May and June of 2006 from both the intervention and comparison groups. During each assessment cycle, the participants completed (a) The Modified Parental Self-Efficacy for Helping the Child Succeed in School Scale (MPSEIICSSS), (b) The Modified Parent Rcport of Encouragement Scale (MPRES), and (c) The Modified Parent Report of Reinforcement (MPRR; HooverDempsey \& Sandler, 2005). These instruments were modified for this study as described in Chapter III. Trained assessors administered cach survey during facc-to-face interviews. Family members who participated in family coaching were also administered a postintervention survey 6 months after the intervention. 
This chapter is organized by demographic data and the following four research questions:

1. After controlling for the pre-intervention level of parental self-cfficacy, is there a difference in the post-intervention measure of parental self-efficacy between families who participated in family coaching and comparison families who did not participate in family coaching?

2. After controlling for the pre-intervention level of parental encouragement, is there a difference in the post-intervention measure of parental encouragement between families who participated in family coaching and comparison families who did not participate in family coaching?

3. After controlling for the pre-intervention level of parental reinforcement, is there a difference in the post-intervention measure of parental reinforccment between families who participated in family coaching and comparison families who did not participate in family coaching?

4. To what extent do families who participate in the Family Coaching Institute report on a survey collected 6 months after the intervention that participation led them to change their attitudes and behaviors about learning at home?

\section{Income}

Students from low-income families do not perform as well academically as students from more affluent families (Desimone, 1999; Epstein, 1995; Kozol, 1991). Crane (1996) and Payne and Biddle (1999) reported that involvement of low-income parents in their children's education had a positive impact on students' academic 
outcomes. Table 6 indicates that $62 \%$ of the intervention group and $80 \%$ of the comparison group had an annual income of less than $\$ 40,000$. Thirty-eight percent of the intervention group had an annual income of $\$ 50,000$ or more, and $20 \%$ of the treatment group had an annual income of more than $\$ 40,000$. Table 6 presents the income range of the participating family members.

Table 6

Income Range of the Participating Family Members

\begin{tabular}{ccccc}
\hline \multirow{2}{*}{ Income range } & \multicolumn{2}{c}{ Intervention } & \multicolumn{2}{c}{ Comparison } \\
\cline { 2 - 5 } & Number & Percent & Number & Percent \\
\hline$\$ 20000$ or Less & 3 & $23 \%$ & 11 & $44 \%$ \\
$\$ 20001-\$ 30000$ & 3 & $23 \%$ & 4 & $16 \%$ \\
$\$ 30001-\$ 40000$ & 2 & $15 \%$ & 5 & $20 \%$ \\
$\$ 40001-\$ 50000$ & & & 1 & $4 \%$ \\
$\$ 50001$ or More & 5 & $38 \%$ & 4 & $16 \%$ \\
\hline
\end{tabular}

\section{Education}

Brody and Flor (1998) found that low-income parents are often less-educated, and research shows that less-educated parents do not become involved in school at the same level as their more well-educated peers. More than $70 \%$ of the intervention group participants had at least some college experience, while only $32 \%$ of the comparison participants had some college experience. Table 7 presents the educational levels of the participating family members. 
Table 7

Educational Level of the Participating Family Members

\begin{tabular}{lrrrr}
\hline \multirow{2}{*}{ Educational level } & \multicolumn{2}{c}{ Intervention } & \multicolumn{2}{c}{ Comparison } \\
\cline { 2 - 5 } & Numbcr & Percent & Number & Percent \\
\hline Less than High School Diploma & & & 7 & $28 \%$ \\
High School Diploma or GED & 1 & $8 \%$ & 6 & $24 \%$ \\
Vocational Study & 2 & $15 \%$ & 4 & $16 \%$ \\
Some College & 6 & $42 \%$ & 6 & $24 \%$ \\
Bachelor's Degree & 2 & $15 \%$ & 1 & $4 \%$ \\
Masters Degree & 2 & $15 \%$ & 1 & $4 \%$ \\
\hline
\end{tabular}

\section{Marital Status}

Children from two-parent families have higher achievement, drop out of school less frequently, and have a higher promotion rate than students from single-parent homes (McLanahan \& Sandefur, 1994). Epstein (1984) found that children from single-parent homes struggle, in part, because teachers have low expectations for them. In addition, low-income single parents arc less likely to participate in school activities (Stevenson \& Baker, 1987). Only $38 \%$ of the intervention and $28 \%$ of the comparison participants were married. Over one third of both groups were never married. The participants' marital status is shown in Table 8.

Table 8

Marital Status of the Participating Family Members

\begin{tabular}{lcccc}
\hline \multirow{2}{*}{ Marital status } & \multicolumn{2}{c}{ Treatment } & \multicolumn{2}{c}{ Comparison } \\
\cline { 2 - 5 } & Number & Percent & Number & Percent \\
\hline Married & 5 & $38 \%$ & 7 & $28 \%$ \\
Separated & 2 & $15 \%$ & & \\
Divorced & 1 & $8 \%$ & 3 & $12 \%$ \\
Never Married & 5 & $38 \%$ & 9 & $36 \%$ \\
Live with Someone & & & 5 & $24 \%$ \\
\hline
\end{tabular}




$$
\text { Age }
$$

All of the participants in the intervention group were 40 years old or less, whereas $20 \%$ of the comparison group were older than 40 years. The age range of the participating family members is shown in Table 9.

Table 9

Age Range of the Participating Family Members

\begin{tabular}{lcccc}
\hline \multirow{2}{*}{ Age range } & \multicolumn{2}{c}{ Trealment } & \multicolumn{2}{c}{ Comparison } \\
\cline { 2 - 5 } & Number & Percent & Number & Percent \\
\hline $22-25$ & 2 & $15 \%$ & 7 & $28 \%$ \\
$26-30$ & 4 & $30 \%$ & 6 & $24 \%$ \\
$31-35$ & 4 & $30 \%$ & 5 & $20 \%$ \\
$36-40$ & 3 & $23 \%$ & 2 & $8 \%$ \\
Over 40 & & & 5 & $20 \%$ \\
\hline
\end{tabular}

There were noticeable differences between the intervention and comparison groups. The intervention group had a higher percentage of participants having some college experience and an annual income of more than $\$ 40,000$. There were no members of the intervention group over 40 years old whilc $20 \%$ of the comparison group was over 40 years old.

\section{Session Attendance}

Fifty-four percent of the participants attended 10 or fewer sessions, and $46 \%$ attended more than 10 sessions. The range of the participants' attendance is shown in Figure 2. 


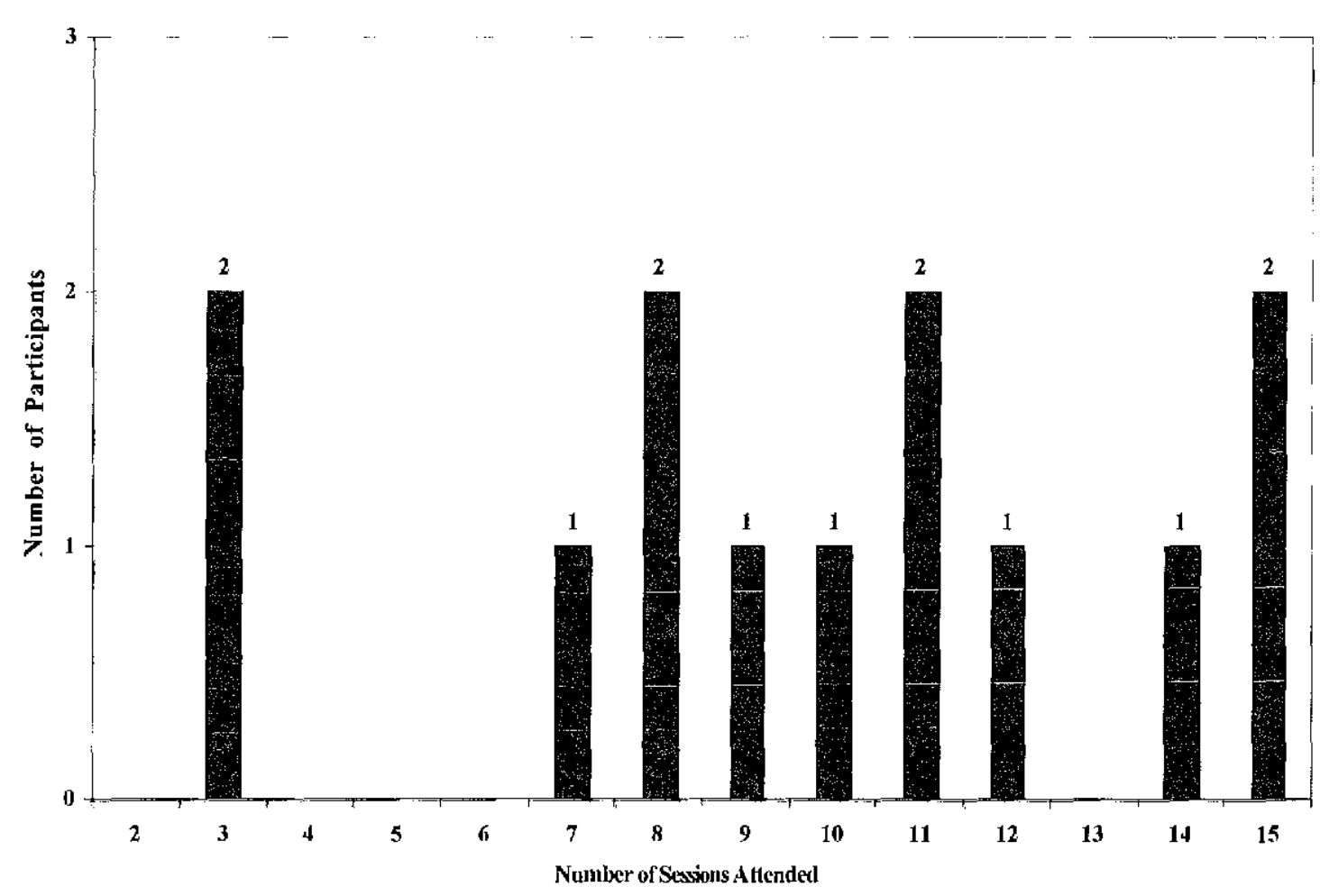

Figure 2. The range of the intervention participants' attendance.

\section{Pre- and Post-Intervention Mean Scores}

Measures of internal consistency, mean scores, and standard deviations for both the comparison and intervention group participants are presented in Table 10. Statistically significant differences between the intervention and comparison groups were not found on any of the pre-intervention interview instruments. The mean scores of the comparison participants increased from pre- to post-intervention on all three instruments. However, the mean scores for the intervention participants decreased on the MPSEHCSSS and MPRES, but not on the MPRR. 
Table 10

Pre- and Post-Intervention Mean Scores

\begin{tabular}{lllllllll}
\hline \multirow{2}{*}{ Scale } & \multirow{2}{*}{ Time } & \multirow{2}{*}{ Alpha } & \multicolumn{3}{c}{ Intervention } & \multicolumn{3}{c}{ Comparison } \\
\cline { 3 - 8 } & & & $n$ & $M$ & \multicolumn{1}{c}{$S D$} & \multicolumn{1}{c}{$n$} & \multicolumn{1}{c}{$M$} & $S D$ \\
\hline MPSEHCSSS* & Pre-Intervention & .517 & 13 & 39.69 & 4.68 & 25 & 36.64 & 3.97 \\
& Post-Intervention & .813 & 13 & 35.61 & 4.91 & 25 & 37.12 & 4.14 \\
MPRR** & Pre-Intervention & .956 & 13 & 71.92 & 12.00 & 25 & 74.72 & 4.27 \\
& Post-Intervention & .913 & 13 & 72.62 & 9.09 & 25 & 74.96 & 4.62 \\
MPRES*** & Pre-Intervention & .887 & 12 & 70.33 & 8.34 & 25 & 73.04 & 5.71 \\
& Post-Intervention & .904 & 13 & 68.38 & 9.85 & 25 & 73.52 & 6.69 \\
\hline
\end{tabular}

* The Modified Parental Self-Efficacy for Helping the Child Succeed in School Scale

** The Modified Parent Report of Reinforcement

*** The Modified Parent Report of Encouragement Scale

\section{Attendance Mean Scores}

The mean attendance and standard deviation for both the participants who attended more than 10 sessions and participants who attended 10 or fewer sessions are presented in Table 11. Participants' attendance was not a statistically significant predictor of the MPSEHCSSS, MPRR, or MPRES scores. However, the mean scale scores of the participants who attended more than 10 sessions were higher than the mean scale scores of the participants who attended less than 10 sessions. The mean scale scores for both groups decreased on the MPSEHCSSS and MPRES from pre-intervention to postintervention; however, the mean scale scores for both groups increased slightly on the MPRR from pre- to post-intervention. 
Table 11

Attendance Mean Scores

\begin{tabular}{llllllll}
\hline \multirow{2}{*}{ Scale } & \multicolumn{2}{c}{ Time } & \multicolumn{3}{c}{10} & sessions or less & \multicolumn{2}{c}{ More than 10 sessions } \\
\cline { 3 - 8 } & & $n$ & $M$ & $S D$ & $n$ & $M$ & $S D$ \\
\hline MPSEHCSSS & Pre-Intervention & 7 & 34.43 & 5.65 & 6 & 38.00 & 2.45 \\
& Post-Intervention & 7 & 33.71 & 5.22 & 6 & 37.83 & 3.76 \\
MPRR ** $^{*}$ & Pre-Intervention & 7 & 68.29 & 15.83 & 6 & 76.17 & 2.23 \\
& Post-Intervention & 7 & 69.00 & 11.36 & 6 & 76.83 & 2.04 \\
MPRES*** & Pre-Intervention & 7 & 66.83 & 10.23 & 6 & 73.83 & 4.36 \\
& Post-Intervention & 7 & 64.57 & 10.28 & 6 & 72.83 & 7.88 \\
\hline
\end{tabular}

* The Modified Parental Self-Efficacy for Helping the Child Succeed in School Scale

** The Modified Parent Report of Reinforcement

*** The Modified Parent Report of Encouragement Scale

\section{Relationship Between Attendance and Mean Scale Scores}

Figure 3 indicates that participants who attended 10 or fewer sessions had lower initial scores on the reinforcement and encouragement scales. Additionally, the scores of the participants who attended 10 or fewer session were more dispersed. In fact, one person who attended three sessions rated herself lower relative to other participants in the 10 or fewer group at both times. The figure is interesting because it clearly shows the group of participants who attended more than 10 sessions reported higher levels of cncouragement and reinforcement before and after the intervention than did the participants who attended 10 or fewer sessions. The encouragement mean scale scores decreased for both groups, but the decrease for participants in more than 10 sessions was not as large. 


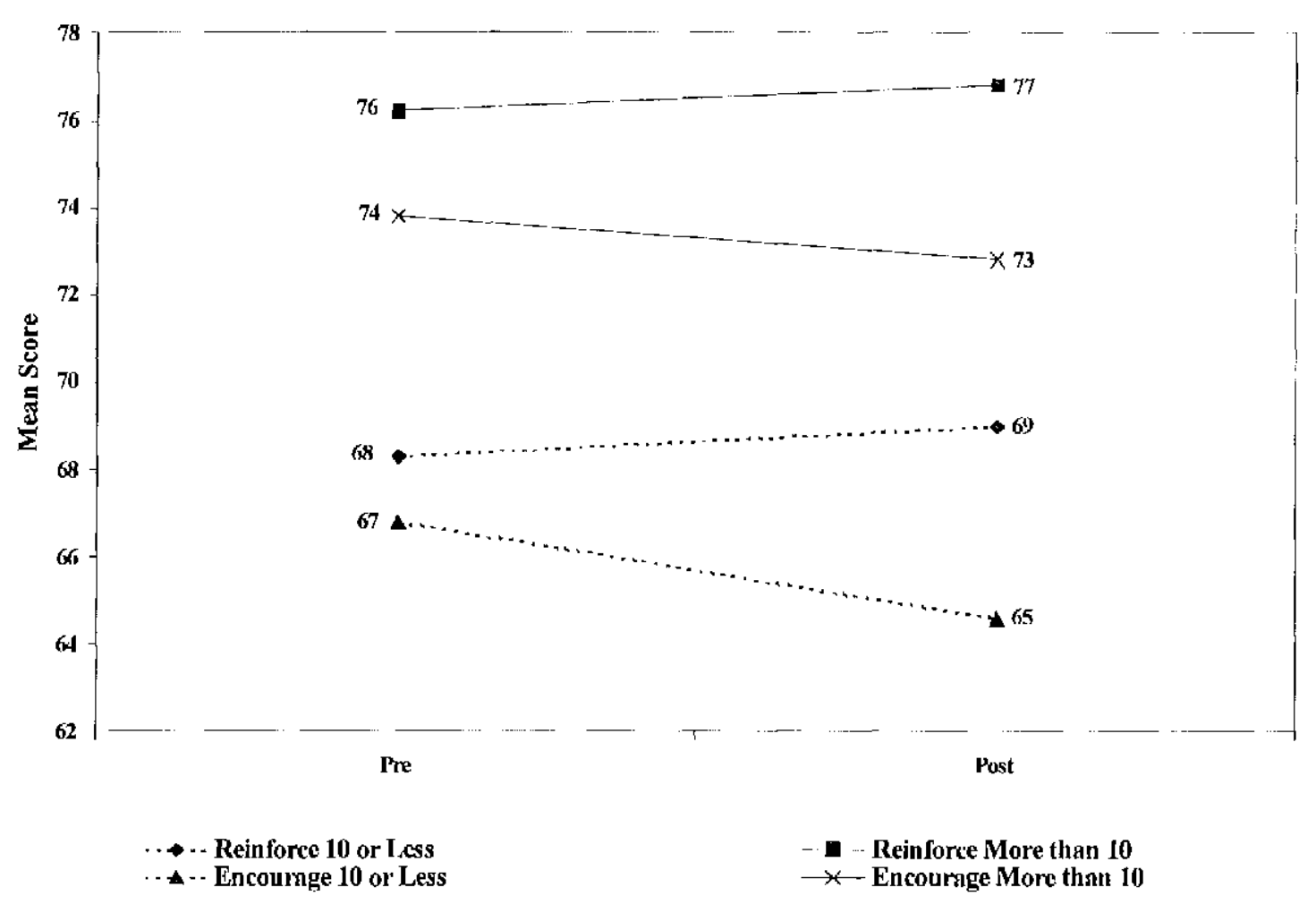

Figure 3. Reinforcement and encouragement attendance means.

\section{Question 1}

After controlling for the pre-intervention level of parental self-eflicacy, is there a difference in the post-intervention mcasurc of parental self-efficacy between families who participated in family coaching and comparison families who did not participate in family coaching?

The MPSEHCSSS data were analyzed using analysis of covariance (ANCOVA) and the results indicated that there was not a statistically significant difference, alpha $=$ .05 , in the post-intervention adjusted mean scale scores betwcen the intervention and comparison groups after controlling for pre-intervention mean scores, $p<.3284$. Table 12 presents the results of this analysis as well as the effect size and $\eta^{2}$. 
Table 12

The Modified Parental Self-Efficacy for Helping the Child Succeed in School Scale (MPSEHCSSS)

\begin{tabular}{lrrrrr}
\hline Source & $d f$ & $F$ & $p$ & $\mathrm{ES}$ & $\eta^{2}$ \\
\hline Intervention & 1 & 10.27 & .3284 & -0.249 & .014 \\
Prctest & 1 & 333.82 & $<.0001$ & & \\
Error & 35 & $(10.45)$ & & & \\
\hline
\end{tabular}

Note. The value in the parenthesis represents the mean square error.

Because the estimated intervention effect was not statistically significant at the alpha $=.05$, the estimated effect size (ES) reported in Table 12, -0.249 , is placed within a 95\% confidence interval based on results in Algina and Keselman (2003), Olcjnik and Algina (2000), and Steiger and Fouladi (1997). The upper limit of the $95 \%$ confidence interval is 0.261 and the lower limit is -0.759 .

\section{Question 2}

After controlling for the pre-intervention level of parental encouragement, is there a diffcrence in the post-intervention measure of parental encouragement between families who participated in family coaching and comparison families who did not participate in family coaching?

The MPRES data were analyzed using analysis of covariance (ANCOVA) and the results indicated that there was not a statistically signifieant difference, alpha $=.05$, in the post-intervention adjusted mean scale scores between the intervention and comparison groups after controlling for pre-intervention mean scores, $p<.2523$. Table 13 presents the results of this analysis as well as the effect size and $\eta^{2}$. 


\section{Table 13}

The Modified Parental Report of Encouragement Scale (MPRES)

\begin{tabular}{lccccc}
\hline Source & $d f$ & $F$ & $p$ & $\mathrm{ES}$ & $\eta^{2}$ \\
\hline Intervention & 1 & 1.36 & .2523 & -0.304 & .025 \\
Pretest & 1 & 17.31 & $<.0001$ & & \\
Error & 34 & $(25.07)$ & & & \\
\hline Note. The value in the parenthesis represents the mean square error.
\end{tabular}

Because the estimated intervention effect was not statistically significant at the alpha $=.05$, the estimated effect size $(E S)$ reported in Table $13,-0.304$, is placed within a 95\% confidence based on results in Algina and Keselman (2003), Olejnik and Algina (2000), and Steiger and Fouladi (1997). The upper limit of the confidence interval is 0.227 and the lower limit is -0.835 .

\section{Question 3}

After controlling for the pre-intervention level of parcntal reinforcement, is there a difference in the post-intervention measure of parental reinforcement between families who participated in family coaching and comparison families who did not participatc in family coaching?

The MPRR data were analyzed using analysis of covariance (ANCOVA) and the results indicated that there was not a statistically significant difference, alpha $=.05$, in the post-intervention adjusted mean scale scores between the intervention and comparison groups after controlling for pre-intervention mean scores, $\mathrm{p}<.6722$. Table 145 presents the rcsults of this analysis as well as the effect size and $\eta^{2}$. 
Table 14

The Modified Parent Report of Reinforcement (MPRR)

\begin{tabular}{lccccc}
\hline Source & $d f$ & $F$ & $p$ & ES & $\eta^{2}$ \\
\hline Intervention & 1 & 3.85 & .6722 & -0.105 & .002 \\
Pretest & 1 & 36.26 & $<.0001$ & & \\
Error & 35 & $(21.13)$ & & & \\
\hline
\end{tabular}

Note. The value in the parenthesis represents the mean square error.

Because the estimated intervention cffect was not statistically significant at the alpha $=.05$, the estimated effect size (ES) reported in Table $14,-0.105$, is placed within a 95\% confidence interval based on results in Algina and Keselman (2003), Olejnik and Algina (2000), and Steiger and Fouladi (1997). 'The upper limit of the confidence intcrval is 0.396 and the lower limit is -0.606 .

\section{Question 4}

To what extent do families who participate in the Family Coaching Institute report on a survey collected 6 months after the intervention that participation led them to change their attitudes and behaviors about learning at home?

To answer Question 4, intervention participants were asked to complete a reflective survey designed to assess the impact of the intervention on participants' attitudes and behaviors measured 6 months after the completion of the Family Coaching Institute (FCI). The survey consisted of six items. Items 1-5 were designed to determine how the intervention influenced the participants' attitudes and behaviors about learning at home. The sixth item asked participants to indicate what they considered to be the most important aspect of the FCI. 
Participants were asked to select responses of 1 to 10 , with 1 indicating strongly disagree and 10 representing strongly agree for items 1-5.

Item 1: Participation in the Family Coaching Institute led me to change the way I think about what helping my child succeed in school means.

Item 2: Participation in the Family Coaching Institute increased my confidence in my ability to help my child learn at homc.

Item 3: Participation in the Family Coaching Institute increased my knowledge of ways to help my child at home.

Item 4: Participation in the Family Coaching Institute has lcd me to spend more time helping my child learn at home.

Item 5: Participation in the Family Coaching Institute has led me to turn everyday experiences into learning opportunities for my child.

Item 6: For me the most important aspect of the Family Coaching Institute was

Table 15 indicates the number of participants who selected particular responses to each statement.

Table 15

FILS Item Means and Intervention Participants' Responses

\begin{tabular}{cccccccccrrr}
\hline \multirow{2}{*}{ Scale } & Item & \multicolumn{10}{c}{ Response catcgories } \\
\cline { 2 - 10 } & means & R1 & R2 & R3 & R4 & R5 & R6 & R7 & R8 & R9 & R10 \\
\hline Item 1 & 8.7 & l & & & & & & & 2 & 3 & 6 \\
Item 2 & 8.5 & & & & & & 1 & 2 & 1 & 8 \\
Item 3 & 9.6 & & & & & & & 1 & & 2 & 9 \\
Item 4 & 9.7 & & & & & & & 1 & 2 & 10 \\
Item 5 & 8.5 & 1 & & & & & & & 2 & 5 & 4 \\
\hline
\end{tabular}

Intervention participants were asked to respond to an open-ended statement by writing out their responses for the sixth item. This item was developed to determine what 
the participants considered to be the most significant aspect of the intervention. Participants were asked to respond to the following statement: "For me the most important aspect of the Family Coaching Institute was..." All participants responded to the question. The responses revealed two primary themes. The main theme of the participants' responses was learning more about how to teach reading at home ( $n=10$, $83 \%$ ). One participant commented, "Going beyond just reading to my child. It helped me take reading and comprehension to the next level by keeping my child involved, interested and learning." Another participant responded, "Learning about different ways to teach my child how to read. My child loved the books and learned a lot about how to read." The other primary theme was learning how to make reading fun $(n=5,41 \%)$. One participant stated, "Learning fun ways to teach my daughter and to spend more time helping her learned [sic] to read." Another participant stated, "Learning how to make reading family fun." A few participants stated that receiving the materials was the most important aspect of the intervention, while some mentioned the positive attitudes of the facilitators as most important to them.

\section{Summary}

Chapter IV presented the findings. The intervention group participants had a higher income, were better educated, and were more likely to be married. Attendance had very little impact on post-intervention mean scale scores; however, those participants who attended more than 10 sessions had higher pre-intervention mean scores. The results of the study indicated that the intervention had very little impact on changing the attitudes and behaviors of those families who participated in the intervention as measured by the 
reinforcement, encouragement, and self-efficacy scales. However, the results also indicated that family members reported that the intervention had a tremendous impact on their attitudes and behaviors 6 months after the intervention. In Chapter V, more in-depth information discussing and summarizing the results will be presented. 
Chapter V: Summary and Discussion

Chapter V of this study restates the problem and provides a brief overview of the methodology. This chapter also provides a summary of the findings from Chapter IV and discusses the implications that can be drawn from the study.

\section{Problem Statement}

There are several differences between schools in low-income and more affluent neighborhoods; one difference associated with higher levels of student achievement is the level at which families are involved in their children's cducation. Awareness of the importance of this diffcrence has led some officials of schools in low-income neighborhoods to adopt initiatives designed to increase the level of family involvement in their schools. Some of these efforts have yielded more involvement; however, many families lack the necessary knowledge, skills, and resources to assist children with learning activities at homc.

\section{Review of Methodology}

The purpose of this study was twofold: to assess the extent to which the Family Coaching lnstitute (FCI) changed parental-self efficacy, the use of encouragement, and the use of reinforcement behaviors; and to ascertain if there were lasting effects of FCI on 
participating families. Families with prekindergarten and kindergarten children attending Fernwood Elementary School and neighboring child care centers were recruited to participate. FCI consisted of three, 5-week institutes. Each institute consisted of five, 2hour biweekly sessions. At each session, families were coached on how to assist their children with learning activities at home. Child care, dinner, materials, books, and supplies were included in the design of FCI. Families practiced learning activitics during FCI and used these activities at home with their children during the days between FCI sessions. Families were interviewed at the beginning and end of FCI to determine if their levels of parental self-efficacy, use of encouragement, and reinforcement behaviors changed. They were also given a reflective post-intervention survey to determine if the effects of FCI lasted over time.

\section{Summary of Results}

Attendance

FCI consisted of 15 sessions, and attendanee ranged from three to all 15 sessions. Fifty-four percent of the participants attended 10 or fewer sessions, and $46 \%$ attended more than 10 sessions. The mean scale scores at pre-intervention on the Modified Parental Self-Efficacy for Helping the Child Succeed in School Scale (MPSEHCSSS), the Modified Parent Report of Encouragement Scale (MPRES) and the Modified Parent Report of Reinforcement (MPRR) at pre-intervention were higher for the participants who attended more than 10 sessions. The participants who attended more than 10 sessions also had higher post-intervention scores on the MPRES and MPRR. 
After controlling for any differences at pre-intervention, there were no statistically significant differences between the intervention and comparison group's mean scores on MPSEHCSSS, MPRES, and MPRR, with $p$-values of $.3284, .6722$, and .2523 , respectively, and alpha $=.05$.

\section{Family Involvement Learning Survey}

FCI participants' responses to the first five items on the FILS were examined to determine the impact FCI had on participants 6 months after FCI. All participants responded with a 7 or higher rating (on a 10-point scale with 10 indicating strong agreement) on all items, with the exception of one participant who responded with a rating of 1 for items 1 and 5 . This participant indicated that the behaviors and attitudes espoused during FCI were congruent with those she held prior to participation. FCI could not increase her beliefs or actions relative to these two items.

Items $1-5$

Item 1: Participation in the Family Coaching Institute led me to change the way I think about what helping my child succeed in school means.

The results of this item (mean response $=8.7$ ) indicate that FCI helped participants understand their role in helping their child succeed in school.

Item 2: Participation in the Family Coaching Institute increased my confidence in ny ability to help my child learn at home.

The results of this item (mean response $=8.5$ ) indicate that participation in FCI increased the perccived self-efficacy of the participants. 
Item 3: Participation in the Family Coaching Institute increased my knowledge of ways to help my child at home.

The results of this item (mean response $=9.6$ ) indicate that participation in $\mathrm{FCI}$ increased participants' understanding of what to do at home relative to children's education.

Item 4: Participation in the Family Coaching Institute has led me to spend more time helping my child learn at home.

The results of this item (mean response $=9.7$ ) indicate participation in $\mathrm{FCI}$ led participants to spend more time helping their children learn at home.

Item 5: Participation in the Family Coaching Institute has led me to turn everyday experiences into learning opportunities for my child.

The results of this item (mean response $=8.5$ ) indicated that participation in $\mathrm{FCI}$ led families to turn everyday activities such as grocery store visits into activitics where learning could take place.

Item 6

Data were gathered from an open-ended item on the FILS to determine which aspect of FCI was most important to the participants. The open-ended statement read: "For me the most important aspect of the Family Coaching Institute was ."By far, most respondents indicated the most important aspect of their participation in FCI was learning how to teach reading at home. The second most frequently cited response was the FCI made lcarning fun, followed by receiving materials and the positive attitude of the staff. 


\section{Discussion of Results}

The FCI was developed to focus on learning at home, which Epstein et al. (1997) identified as the most important area of family involvement. The FCI also focused on changing family members' perception of their role as their child's teacher, on increasing their knowledge of strategies to use to help their child, and on increasing the skills needed to engage their child in learning activities. The changed perceptions and increased knowledge and skills were expected to lead to a higher sense of self-efficacy, and an increasc in the use of encouragement and reinforcement behaviors, factors which according to Hoover-Dempsey and Sandler (2002), are the motivating conditions associated with family involvement.

The FCI was designed to include strategies to increase the involvement of participants in decisions about the structure of the program (Callahan et al.,1998). These strategies were found in both comprehensive models (Comer \& Haynes, 1999 Epstein ct al., 1997) and targeted programs (Jordan et al., 2000; Colgan, 2002).These strategies were associated with increased levels of involvement and school success. The FCI intervention also sought to overcome barriers to involvement such as the lack of resources by providing materials and supplies (Smith, 2001). As presented in Chapter IV, the expected results were not realized.

First, a relationship between family coaching and perceived parental self-efficacy was not shown. Moreover, while not statistically significant, the results indicated that family coaching possibly led to a small decrease in perceived parental self-efficacy.

Second, the results did not show a relationship between family coaching and perceived reinforcement behavior. While there was a small gain in mean scale scores 
between pre- and post-intervention, the increase in pcrceived reinforcement behavior associated with family coaching was not statistically significant.

Third, a relationship between fatnily coaching and perceived encouragement was not found. The results were similar to the perceived self-efficacy results in that a small, but a statistically non-significant decrease in the encouragement of the participants was found.

The decrease in mean scale scores could indicate that both the intervention and comparison groups answered the instrument feeling confident about their ability to help their children learn at home before $\mathrm{FCI}$ began. The intervention participants began FCI believing they were doing a good job assisting their children with lcarning. As FCI began, the family coaches started teaching families effective use of strategies and techniques for learning. As these families started participating in FCI, they may have found that they were unaware of many of the behaviors, attitudes, and strategies that research indicates are most effective for student success. Therefore, families may not have truly understood the knowledge and skills needed to fill their role as a teacher at home prior to $\mathrm{FCl}$ participation. As families continued attending $\mathrm{FCl}$, they gained knowledge and skills to apply at home. The gain in knowledge and skills coupled with a clearer understanding of the role of the parent as teacher may have led families who participated in FCI to think differently about scale items during the post-intcrvention interview.

Six months after the end of $\mathrm{FCl}$, participants were administered the Family Involvement Learning Survey (FILS). They expressed confidence in their parental abilities and responded to the items expressing gains in parenting knowledge and skills. I 
believe that the less they knew, the higher they rated themselves and the morc they learned the lower they rated themselves on the modified scales. Therefore, their scores on the pre-intervention interviews may reflect an actual lack of knowledge and skills families had before FCI.

The FII S was designed to specifically measure knowledge, attitudes, and behaviors emphasized in FCI; therefore, participants' responses reflect the goals and purposes of FCI. Furthermore, $85 \%$ of the participants stated that learning how to teach their child how to read was the most important aspect of FCI. Most participants mentioned that after the intervention they were more knowledgeable about reading, spent more time reading to their children, had a better understanding of and were more confident in their role as their children's teacher, and made everyday situations opportunities for learning.

\section{Explanation of Unanticipated Results}

Although FCI is grounded in current research, the immediate measure of the effectiveness of FCI produced unexpected results. The results indicated FCI had little or possibly even a negative impact measured on some of the post-intervention modified scales used immediately following FCI. I believe the unanticipated results of this study can be explained by Howard's (1980) Response Shift Bias (RSB) theory. According to Iloward, a RSB indicates changes occur in the participant's knowledge, behaviors, and attitudes during the intervention and these changes may lower posttest scores. As a result, participants will respond to posttest items with a different understanding than they responded at pretest. Poll (1982) found that whenever RSB occurs, little or no difference 
is shown between pretest and posttest responses, and pretest responses may actually be invalid. It is therefore possible for a participant to score average on a pretest, participate in an intervention, and also score average on the postlest. Rohs (1999) suggested that new learning and better understanding causes lower ratings on posttests, thereby contaminating data.

Howard (1980) suggested to reduce RSB evaluators can use a then/post method for evaluating program effectiveness. Participants will only respond to a survey at the end of an intervention but will respond to cach item twice. First, participants respond to the items based on their current thinking and then respond a second time based on their thinking before the intervention. The then/post responses of the participants are more accurate since the respondent's understanding of the measured constructs (knowledge, skills, and attitudes) will be consistent for both the then and post surveys. (Rockwell \& Kohn, 1989; Davis, 2005). Therefore, because then/post ratings are done at the same time, they are free of RSB.

Rohs (1999) investigated RSB in a study of the effectiveness of a leadership intervention by using two treatment groups and a control group. The control croup was given the Youth Leadership Life Skills Development Scale (YLLSDS) as a pretest and posttest without experiencing the intervention. Both treatment groups completed an intervention which included the 10-week leadership program. Treatment Group 1 took the YLLSDS as a pretest and posttest survey, and Treatment Group 2 took the YLLSDS as a then/posttest survey. No statistically significant intervention effect was found for Treatment Group 1 as there were no statistically significant gains from the pretest to posttest scores for either Treatment Group 1 and Treatment Group 2. However, when 
comparing the gains from pretest to posttest for Treatment Group 1 and Treatment Group 2, an intervention effect was found for Treatment Group 2. Data from the pretest/posttest group (Treatment Group 1) clearly indicated that the leadership program was not effective since there were no measured gains, but the data from the then/posttest group clearly indicated the effectiveness of the leadership intervention.

\section{Implications}

Educators should consider the lcvel of knowlcdge, skills, and resources of their families before developing or beginning a family involvement program. This would ensure that schools are not providing strategies that families do not understand or are not able to use due to a lack of knowledge, skills, and resources.

To maximize family involvement interventions, school staff should consider coaching families, as was done in this study. Coaching provides strategies to overcome barriers to family involvement. Coaching allows program staff to model expected behaviors, to provide opportunities to practice strategies, and to give immediate fecdback. Coaching also helps families develop thcir skills, which in turn influences their expectations for their roles and also helps them to develop a positive relationship with the school.

\section{Recommendations for Further Research}

The results of this study led me to make the following recommendations for future research on families' involvement in their children's education. More participants are needed so that expcrimental designs can be used. The intensity of this intervention 
could be increased from a 30 -hour, 15 -session intervention to a study with more sessions and more hours which may yield more positive changes. More innovative strategies should be used to recruit participants in addition to the traditional strategies used in this study.

Future researchers should be mindful of the limitations of the pretest/posttest design when assessing participants' perceptions of their initial knowledge, attitudes and behaviors. I recommend using Rohs' (1999) methodology in evaluating future family involvement interventions.

When evaluating family involvement interventions, researchers should be carcful to evaluate the program's effectiveness by controlling for response shift bias.

\section{Recommendations for Practice}

Most of the family involvement research focuses on programs that merely inform families of stratcgies they can implement at home without providing coaching. Very few family involvement programs take into consideration that families may not have the knowledge, skills, and resources to implement recommended strategies. This study posited that families would have more success if they were coached to use strategies (to increase their engagement in children's learning) and were provided resourecs, opportunities for practice, and feedback.

School personnel typically send home flyers telling families to read to their children without knowing if the families know how to rcad, without knowing if books are in the home or if there is funding to purchase books. For family involvement interventions to be successful for low-income families, school staff must do more than 
just provide information. School staff must ensure families have the knowledge, skills, and resources needed to use the recommended strategies.

Coaching families provides the opportunity to extend the competence of the families and increase positive interactions between families and school staff. This allows the development of school programs that are aligned with the needs of families. To cnhance family involvement school staffs must:

1. Determine the skill and knowledge base of families.

2. Determine what resources families have available.

3. Develop programs that are aligned with families' needs.

4. Allow families the opportunity to help develop the program.

5. Provide coaching aligned with the families need to be successful.

\section{Conclusion}

Family involvernent has been defined differently by parents, students, educators, policy makers, and scholars. Though thcre are many definitions, most tend to believe that families are important to a child's academic success. To increasc student achievement, researchers have developed many programs and educators have used many strategies.

To positively impact student outcomes, it should not be assumed that families can simply use stratcgies provided by schools or simply participate in family involvement programs and become successful teachers at home. Barricrs such as the lack of knowledge, the lack of skills, and that lack of resources should be taken into consideration when programs and strategies are being developed. Developers of the most successful family involvement programs determinc which barriers must be overcome, 
focus on a single subject or condition, provide coaching along with modeling, and involve families in the development of the programs.

Researchers must be careful in evaluating the effectiveness of family involvement programs. In some cases pretest and posttest measures do not reveal the effectiveness of these programs. Alternative measures such as then/posttest measures may provide more accurate results and descriptions of the true impact of the program. 
Appendices 
Appendix A

Family Coaching Institute Table of Specification 


\section{INSTITUTE I: OCTOBER 17 $7^{\mathrm{TH}}$ - DECEMBER $16^{\mathrm{TH}}$}

GLAD - Gear up for Literacy Activities Daily

INSTITUTE GOAL: Participants will develop skills needed to be effective teachers of their children.

\begin{tabular}{|c|c|c|c|c|c|}
\hline $\begin{array}{l}\text { G.L.A.D. } \\
\text { Gatherings }\end{array}$ & Family Conversations & Dinner Discussion & $\begin{array}{l}\text { Literacy Coaching } \\
\text { (Literacy component: } \\
\text { Connecting discussion to } \\
\text { implementation of bags) }\end{array}$ & $\begin{array}{l}\text { Family Literacy Bag Books } \\
\text { "G.L.A.D. Bags" } \\
\text { (Bags included activities related to } \\
\text { each book.) }\end{array}$ & $\begin{array}{l}\text { Children's } \\
\text { Club (Literacy } \\
\text { focused } \\
\text { activities } \\
\text { around selected } \\
\text { book) }\end{array}$ \\
\hline $\begin{array}{c}\text { Week of } \\
\text { October } 17^{\text {th }}\end{array}$ & $\begin{array}{l}\text { Starter Activity: Play } \\
\text { Centers (blocks, water, } \\
\text { sand, clay, puzzles) } \\
\text { Family Conversations: } \\
\text { Play Centers Discussion } \\
\end{array}$ & $\begin{array}{c}\text { Play - Child's Work, } \\
\text { Parent's Role }\end{array}$ & $\begin{array}{l}\text { Reading Aloud: } \\
\text { Reading to and with } \\
\text { Your Child }\end{array}$ & $\begin{array}{l}\text { 1. Chicka Chicka Boom Boom } \\
\text { 2. The Giraffe Made Her Laugh } \\
\text { 3. Plumply, Dumply Pumpkin }\end{array}$ & $\begin{array}{l}\text { The Giraffe } \\
\text { Made Her } \\
\text { Laugh }\end{array}$ \\
\hline $\begin{array}{c}\text { Week of } \\
\text { October } 31^{\text {st }}\end{array}$ & $\begin{array}{l}\text { Starter Activity: } \\
\text { Talking Tic-Tac-Toe } \\
\text { Family Conversations: } \\
\text { Language of a Child }\end{array}$ & $\begin{array}{l}\text { Let's Talk About It: } \\
\text { Having Conversation } \\
\text { with Your Child }\end{array}$ & $\begin{array}{l}\text { Oral Language, } \\
\text { Listening, and } \\
\text { Vocabulary } \\
\text { Development: Talking } \\
\text { and Listening to Your } \\
\text { Child } \\
\end{array}$ & $\begin{array}{l}\text { 1. The Farm Concert } \\
\text { 2. The Very Busy Spider } \\
\text { 3. Who Took the Cookies from the } \\
\text { Cookie Jar? }\end{array}$ & $\begin{array}{l}\text { Who Took the } \\
\text { Cookies from } \\
\text { the Cookie Jar? }\end{array}$ \\
\hline $\begin{array}{l}\text { Week of } \\
\text { November } \\
14^{\text {th }}\end{array}$ & $\begin{array}{l}\text { Starter Activity: } \\
\text { Changing Don'ts to Dos } \\
\text { Family Conversations: } \\
\text { Creating a Language- } \\
\text { Rich Environment }\end{array}$ & $\begin{array}{c}\text { The Language of the } \\
\text { Home }\end{array}$ & $\begin{array}{l}\text { Oral Language, } \\
\text { Listening, and } \\
\text { Vocabulary } \\
\text { Development: } \\
\text { Strengthening Your } \\
\text { Child's Vocabulary }\end{array}$ & $\begin{array}{l}\text { 1. Brown Bear, Brown Bear, What } \\
\text { Do You See? } \\
\text { 2. One Little, Two Little, Three } \\
\text { Little Pilgrims } \\
\text { 3. Panda Bear, Panda Bear, What } \\
\text { Do You See? }\end{array}$ & $\begin{array}{l}\text { Brown Bear, } \\
\text { Brown Bear, } \\
\text { What Do Yous } \\
\quad \text { See? }\end{array}$ \\
\hline $\begin{array}{l}\text { Week of } \\
\text { November } \\
28^{\text {th }}\end{array}$ & $\begin{array}{l}\text { Starter Activity: My } \\
\text { Mother and Father } \\
\text { Family Conversations: } \\
\text { Nurturance }\end{array}$ & $\begin{array}{l}\text { Developing Secure } \\
\text { Attachments }\end{array}$ & $\begin{array}{l}\text { Letter and Sound } \\
\text { Knowledge: Learning } \\
\text { Letters }\end{array}$ & $\begin{array}{l}\text { 1. A Mother for Choco } \\
\text { 2. Feast for Ten } \\
\text { 3. 'Twas the Day After Thanksgiving }\end{array}$ & Feast for Ten \\
\hline $\begin{array}{l}\text { Week of } \\
\text { December } \\
12^{\text {th }}\end{array}$ & $\begin{array}{l}\text { Starter Activity: Rituals } \\
\text { and Routines } \\
\text { Family Conversations: } \\
\text { Family Traditions }\end{array}$ & $\begin{array}{l}\text { The Importance of } \\
\text { Traditions }\end{array}$ & $\begin{array}{l}\text { Letter and Sound } \\
\text { Knowledge: Letter } \\
\text { Lessons }\end{array}$ & $\begin{array}{l}\text { 1. If You Take a Mouse to the } \\
\text { Movies } \\
\text { 2. My Favorite Bear } \\
\text { 3. Where, Oh Where, Is Kipper's } \\
\text { Bear? }\end{array}$ & $\begin{array}{c}\text { Where, Oh } \\
\text { Where, Is } \\
\text { Kipper's Bear? }\end{array}$ \\
\hline
\end{tabular}


INSTITUTE II: JANUARY 9 ${ }^{\mathrm{TH}}$ - MARCH $10^{\mathrm{TH}}$

PEDAL - Pause Each Day for Activities in Literacy

INSTITUTE GOAL: Participants will explore strategies and parenting behaviors that are essentials of a home environment that supports learning.

\begin{tabular}{|c|c|c|c|c|c|}
\hline $\begin{array}{l}\text { P.E.D.A.L. } \\
\text { Parties }\end{array}$ & Family Conversations & Dinner Discussion & $\begin{array}{l}\text { Literacy Coaching } \\
\text { (Literacy component: } \\
\text { Connecting discussion to } \\
\text { implementation of bags) }\end{array}$ & $\begin{array}{c}\text { Family Literacy Bag Books } \\
\text { "P.E.D.A.L. Packs" } \\
\text { (Experiences with bags that will go } \\
\text { home) }\end{array}$ & $\begin{array}{l}\text { Children's } \\
\text { Club (Literacy } \\
\text { focused } \\
\text { activities } \\
\text { around selected } \\
\text { book) }\end{array}$ \\
\hline $\begin{array}{l}\text { Week of } \\
\text { January } 9^{\text {th }}\end{array}$ & $\begin{array}{l}\text { Starter Activity: Brain } \\
\text { Teasers and Handshakes } \\
\text { Family Conversations: } \\
\text { Remembering What } \\
\text { We've Learned }\end{array}$ & $\begin{array}{c}\text { Getting to Know You- } \\
\text { Let's Talk! }\end{array}$ & $\begin{array}{l}\text { Phomological } \\
\text { Awareness: Playing } \\
\text { with Sounds }\end{array}$ & $\begin{array}{l}\text { 1. Bright Eyes, Brown Skin } \\
\text { 2. Kipper } \\
\text { 3. Kipper's Snowy Day }\end{array}$ & $\begin{array}{c}\text { Kipper and } \\
\text { Kipper's Snowy } \\
\text { Day }\end{array}$ \\
\hline $\begin{array}{c}\text { Week of } \\
\text { January } 23^{\text {rd }}\end{array}$ & $\begin{array}{c}\text { Starter Activity: What I } \\
\text { Like Best About } \\
\text { Parenting } \\
\text { Family Conversations: } \\
\text { Parenting Styles and } \\
\text { Climate of the Home }\end{array}$ & $\begin{array}{l}\text { Sunny Home } \\
\text { Environments }\end{array}$ & $\begin{array}{l}\text { Phonological } \\
\text { Awareness: Playing } \\
\text { with Sounds in Words }\end{array}$ & $\begin{array}{l}\text { 1. Mouse Paint } \\
\text { 2. Snowballs } \\
\text { 3. The Very Hungry Caterpillar }\end{array}$ & $\begin{array}{l}\text { The Very Lazy } \\
\text { Ladybug and } \\
\text { The Very } \\
\text { Hungry } \\
\text { Caterpillar }\end{array}$ \\
\hline $\begin{array}{c}\text { Week of } \\
\text { February } 6^{\text {th }}\end{array}$ & $\begin{array}{l}\text { Starter Activity: Make } \\
\text { a Valentine } \\
\text { Family Conversations: } \\
\text { What Animal Are You? }\end{array}$ & Temperament Talk & $\begin{array}{l}\text { Phonological } \\
\text { Awareness: Playing } \\
\text { with Sounds in Words }\end{array}$ & $\begin{array}{l}\text { 1. Clifford's First Valentine's Day } \\
\text { 2. Five Little Ducks } \\
\text { 3. Pretend You're a Cat }\end{array}$ & $\begin{array}{l}\text { Clifford's First } \\
\text { Valentine's } \\
\text { Day and Five } \\
\text { Little Ducks }\end{array}$ \\
\hline $\begin{array}{l}\text { Week of } \\
\text { February } \\
21^{\text {st }}\end{array}$ & $\begin{array}{c}\text { Starter Activity: } \\
\text { Dominoes } \\
\text { Family Conversations: } \\
\text { A Day in the Life }\end{array}$ & Your Child's Future & $\begin{array}{c}\text { Emergent Writing: } \\
\text { Writing with Your Child }\end{array}$ & $\begin{array}{l}\text { 1. Bailey Goes Camping } \\
\text { 2. Brush Your Teeth, Please! } \\
\text { 3. Good Thing You're Not an } \\
\text { Octopus! }\end{array}$ & $\begin{array}{l}\text { Brush Your } \\
\text { Teeth Please! }\end{array}$ \\
\hline $\begin{array}{l}\text { Week of } \\
\text { March } 6^{\text {th }}\end{array}$ & $\begin{array}{c}\text { Starter Activity: } \\
\text { Telling Time Games } \\
\text { Family Conversations: } \\
\text { Time Management } \\
\end{array}$ & $\begin{array}{c}\text { Time Management }= \\
\text { Stress Reduction }\end{array}$ & $\begin{array}{l}\text { Print Concepts: Print } \\
\text { Concepts the Fun Way }\end{array}$ & $\begin{array}{l}\text { 1. Down on the Farm } \\
\text { 2. If You Take a Mouse to School } \\
\text { 3. Who's Hatching? }\end{array}$ & $\begin{array}{c}\text { Down on the } \\
\text { Farm }\end{array}$ \\
\hline
\end{tabular}




\section{INSTITUTE III: MARCH $27^{\mathrm{TH}}-$ MAY $26^{\mathrm{TH}}$}

LEADER - Literacy Experiences and Activities Daily Evolving into Routines

INSTITUTE GOAL: Participants will prepare to be leaders by facilitating family workshops.

\begin{tabular}{|c|c|c|c|c|c|}
\hline $\begin{array}{l}\text { L.E.A.D.E.R } \\
\text { Celebrations }\end{array}$ & Family Conversations & Dinner Discussion & $\begin{array}{c}\text { Literacy Coaching } \\
\text { (Literacy component: } \\
\text { Connecting discussion } \\
\text { to implementation of } \\
\text { bags) }\end{array}$ & $\begin{array}{l}\text { Family Literacy Bag Books } \\
\text { "L.E.A.D.E.R Sacks" } \\
\text { (Experiences with bags that will go } \\
\text { home) }\end{array}$ & $\begin{array}{c}\text { Children's } \\
\text { Club (Literacy } \\
\text { focused } \\
\text { activities } \\
\text { around selected } \\
\text { book) } \\
\end{array}$ \\
\hline $\begin{array}{l}\text { Week of } \\
\text { March } 27^{\text {th }}\end{array}$ & $\begin{array}{l}\text { Starter Activity: } \\
\text { Follow the Leader } \\
\text { Family Conversations: } \\
\text { What is a LEADER? }\end{array}$ & $\begin{array}{l}\text { Becoming a Family } \\
\text { Literacy Expert }\end{array}$ & $\begin{array}{c}\text { Conversations About } \\
\text { Books }\end{array}$ & $\begin{array}{l}\text { 1. The Big Leaf Pile } \\
\text { 2. Clifford Makes a Friend } \\
\text { 3. The Little Yellow Chicken }\end{array}$ & $\begin{array}{l}\text { The Little } \\
\text { Yellow Chicken }\end{array}$ \\
\hline $\begin{array}{l}\text { Week of } \\
\text { April } 10^{\text {th }}\end{array}$ & $\begin{array}{c}\text { Starter Activity: } \\
\text { Favorite Books at My } \\
\text { House } \\
\text { Family Conversations: } \\
\text { Strategies for } \\
\text { Conducting Family } \\
\text { Literacy Workshops } \\
\end{array}$ & $\begin{array}{l}\text { Hosting Family } \\
\text { Festivals in the Home }\end{array}$ & $\begin{array}{c}\text { Vocabulary: Fun Fact } \\
\text { Words }\end{array}$ & $\begin{array}{l}\text { 1. The Flower Garden } \\
\text { 2. Jump, Frog, Jump } \\
\text { 3. Puddles }\end{array}$ & $\begin{array}{l}\text { Jump, Frog, } \\
\text { Jump }\end{array}$ \\
\hline $\begin{array}{l}\text { Week of } \\
\text { April } 24^{\text {th }}\end{array}$ & $\begin{array}{c}\text { Starter Activity: } \\
\text { Mother's Day } \\
\text { Reflection } \\
\text { Family Conversations: } \\
\text { Role Play: Practice } \\
\text { Conducting Family } \\
\text { Literacy Workshops }\end{array}$ & PEDAL Prep & $\begin{array}{c}\text { Rhyming: Down by the } \\
\text { Bay }\end{array}$ & $\begin{array}{l}\text { 1. Down by the Bay } \\
\text { 2. Does a Kangaroo Have a } \\
\text { Mother, Too? } \\
\text { 3. What Mommies Do Best }\end{array}$ & $\begin{array}{l}\text { Down by the } \\
\text { Bay and Does a } \\
\text { Kangaroo Have } \\
\text { a Mother, Too? }\end{array}$ \\
\hline $\begin{array}{l}\text { Week of } \\
\text { May } 8^{\text {th }}\end{array}$ & \multirow{2}{*}{\multicolumn{3}{|c|}{$\begin{array}{l}\text { Participants will work in two teams to conduct PEDAL } \\
\text { workshops with Cohort Two participants. }\end{array}$}} & $\begin{array}{l}\text { 1. Mrs. Wishy-Washy } \\
\text { 2. The Scrubbing Machine } \\
\text { 3. Shake My Sillies Out }\end{array}$ & $\begin{array}{l}\text { Meanies and } \\
\text { Do Not Open } \\
\text { This Book! }\end{array}$ \\
\hline $\begin{array}{l}\text { Week of } \\
\text { May } 22^{\text {nd }}\end{array}$ & & & & $\begin{array}{l}\text { 1. Here Are My Hands } \\
\text { 2. The Icky Sticky Chameleon } \\
\text { 3. Silly Sally }\end{array}$ & $\begin{array}{c}\text { The Icky Sticky } \\
\text { Chameleon }\end{array}$ \\
\hline
\end{tabular}


Appendix B

Family Member Self-Reported Level Engagement 


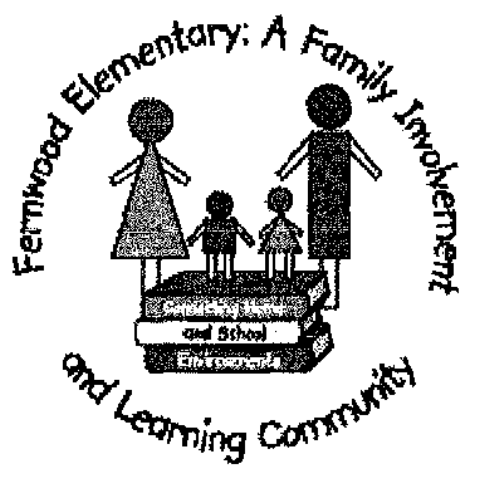

Fernwood Elementary: A Family Involvement and Learning Community Family Survey

Name

Date

\begin{tabular}{|l|l|l|}
\hline Book Title & $\begin{array}{l}\text { How many times did } \\
\text { you read the book with } \\
\text { your child? }\end{array}$ & $\begin{array}{l}\text { How many activities } \\
\text { related to the book } \\
\text { did you complete? }\end{array}$ \\
\hline & & \\
\hline & & \\
\hline
\end{tabular}

1. Did you talk to the Family Coach? Yes

No If yes, how many times?

2. Have you discussed this project with family/friends? Yes No If yes, about how many times?

3. What did you like best about this PEDAL Pack? 
Appendix C

Institutional Revicw Board Letter of Approval 
Division of Sponsared Research and Training

\section{MEMORANDUM}
TO: $\quad$ Dr. Madelaine Cosgrove, Florida Institute of Education
FROM: Dr, Kathaleen Bloom, Chair, UNF Institutional Review Board
DATE: $\quad$ October 4,2005
RE: $\quad$ Revlew by the Institutional Review Board \#01-044:
"Early Literacy and Learning Model (ELLM)"

This is to advise you that the proposed modifications to the family involvement component of your project, "Eanly Literacy and Learning Model (ELLM)," have been reviewed and approved on behalf of the Institutional Review Board to include the following:

- Implementation of the S.P. Livingston Family Involvement and Early Leaming Hub at one elementary school and seven child care centers in the surrounding neighborhood.

- Participation of parents/guardians of approximately 200 children at the approved sites to include (1) bi-weekly family workshops at the school, (2) carrying out family literacy activlties at home, and (3) engaging in family-fnendly activities within the community as explained in your proposal.

- Assessment of both parents and children to include (1) parent participation in family interviews, and (2) administration of the ALRI, the TERA-3, and the PPVTIII to child participants.

This approval applies to your project in the form and content as submitted to the IRB for review. Any varlations or modifications to the approved protocol and/or informed consent forms as they relate to dealing with human subjects must be cleared with the IRB prior to implementing such changes.

Should you have any questions regarding your project or any other IRB issues, please contact Nicole Sayers, Coordinator of Research Compliance, at 620-2498.

nms

c: Cheryl Fountain, Ed.D. 


\section{FLORIDA INSTITUTE OF EDUCATION}

at the University of North Florida

MEMORANDUM

TO:

Dr, Kathaleen Bloom

Chair. Internal Review Board (IRB)

FROM:

Dr. Madelaine Cosgrove

Florida Institute of Edudatition

Associate Director for School Readiness

UNF IRB Number: Approval Date:

Revision Date:

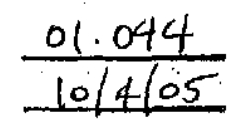

DATE: September 28, 2005

SUBJ: Request for Expansion of the Early Literacy and Learning Model (ELLM) - Duval

(1) Revised Family Model (2) New Classrooms (3) New Assessments

(4) Family Coaching Component

The Florida Institute of Education at the University of North Florida, designers of the Early Literacy and Learning Model (ELLM), are revising the family involvement component of ELLM. The revised model, using a family coaching component, is designed to:

1. Identify and inplement promising strategies that significantly increase the active engagement of families in their children's leaning.

2. Connect the home and school environments so that they share critical components associated with learning.

3. Enable families to help their children develop early literacy knowledge and skills.

4. Help programs and schools become places where family involvement is welcomed and supportcd, and whero communication among families, programs, and schools is fostered.

5. Improve children's readiness outcomes with a focus on literacy.

The S. P. Livingston Family Involvement and Early Leaming Hub will be implemented in 1 elementary school (pre-kindergarten and kindergarten) and 7 child care centers in the surrounding neighborhood. Six of the child care centers are currently participating in the Rally, Jacksonville! Initiative; the seventh center is a former ELLM site.

Parents/guardians of children in these sites will be invited to participate in this program which includes (1) participating in bi-weekly family workshops at the school, (2) carrying out family literacy activities at home (activities will be provided as part of the study, and (3) engaging in family-friendly activities within the community (tickets/needed admission information will be provided as part of the study). To support parents as they participate in the study, a coaching model will be used, A doctoral student at The University of North Florida will use interview results to determine if family coaching increases parental self-efficacy, encouragement, and reinforcement.

University of Norch Florida - University Center • 12000 Alumni Drive • Jacksonville, Filorida 32224-2678

(904) 620-2496 • FAX (904) 620-2454 - http://www.fie.unt.edu 
Parents will receive $\$ 10$ for each interview completed. We anticipate 200 families will sign up to participate.

To assess the impact/effectiveness of the revised family model, we will assess both parents and children.

Parents will be asked to participate in two family interviews, one at the beginning of the program and another at the end of the program. The parent interview is a combination of several parent surveys with reliability and validity. Questions from the original surveys have been modified to address the level of child's education and/or omitted as irrelevant to the study. No new questions have been added. The order of questions has been shifted in a few instances - only for smoothness in conducting the interview. A copy of the final interview document is attached.

In order to determine the impact of the program on children's emergent literacy skills and school readiness, the Alphabet Letter Recognition Inventory (ALRI), the Test of Early Reading Ability $-3^{\text {rd }}$ Ed. (TERA-3), and the Peabody Picture Vocabulary Test $-3^{\text {rd }}$. Ed (PPVT-III) will be administered to each child. Teachers will administer the ALRI and trained assessors will administer the TERA-3 and the PPVT-III. Teachers will be asked to complete the Pre-School Learning Behavior Scale for each child assessed and will be given $\$ 5,00$ for each learning scale completed.

The ALRI is a locally developed assessment designed to assess children's ability to recognize the upper- and lower-case letters of the alphabet. The TERA-3 is a standardized measure which assesses children's emergent literacy skills and readiness for school. The PPVT-III is a standardized measurement of children's receptive vocabulary.

Copies of the child assessments are attached.

In addition to the parent interview and child assessments, I am attaching the Parent/Guardian Informed Consent for Parent and Child Participation.

Please review the attached documents and provide certification that we may proceed with the study. If you have any questions or concerns, please call me or Dr. Rebecca England, Family Involvement Specialist, at 2496.

Thank you for your efforts on our behalf.

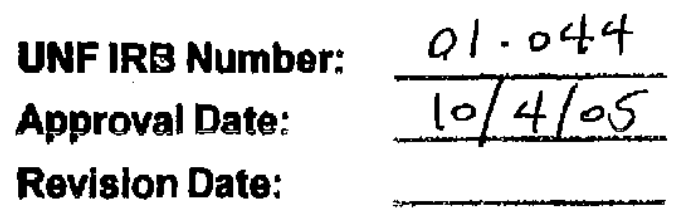




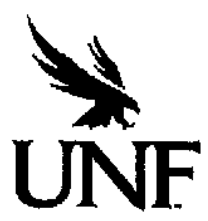

\section{University of North Florida \\ Divislon of Sponsored Research and Training \\ AMENDMENT REQUEST}

\section{Request to modify a protocol previously approved by the UNF Institutional Review Board for the Protection of Human Subjects}

\section{To Be Completed by the Principal Investigator:}

Principal Investigator: Dr. Madeline Cosgrove

Faculty Advisor (if student project):

College/Dept.: FIE

Campus Address \& Phone: 12000 Alumni Drive, Bldg. 43: $904-620-2496$

Project Title: Early Literacy and Learning Model (ELLM)

IRB Protocol \#: $01 \cdot 044$ Date of Original IRB Approval:

IRB Classification: $\square$ Exempt/Category \#

$\square$ Expedited/Category \# \Full IRB

Project Type: $\square$ Non-funded (or student research) $\bigotimes$ Externally Funded Research

Supporting Agency (if any) Deadline:

Date Amendment Request Submitted to ORSP for Project Termination Date: ongoing Review: 9/28/2005

Typo Reviow Requested: $\square$ Exempt/Category \# $\square$ Expedited/Category \#

$\square$ Full IRB

\section{FOR IRB USE:}

Regulatory/Ethical justification for type of review: CFR 45, Part 46

* fall-6ozard review

IRB Classification:

$\square$ Same as provious approval

Subjects at Risk:

$\square$ Yes

$\square$ No

Other/Re-classification (Type) hot reguired for

If yes, potential benefits justify proceedings $\quad \square$ Yes $\quad \square$ No

1st Modification Review By: Signature Deleted ? member signature and date)

Approved $\square$ Revisions Required (attach comments) $\square$ Referred to Full IRB 2nd Modification Review By: (member signature and date)

Approved $\square$ Revisions Required (attach comments) $\square$ Referred to Full IRB 
Appendix D

Participants Informed Consent Form 


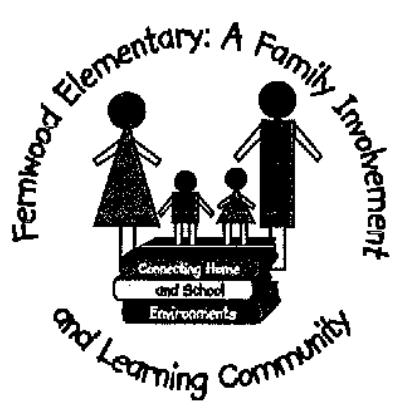

\title{
Fernwood Elementary: A Family Involvement and Learning Community: An Expansion of the ELLM Family Model
}

\author{
PARENT/GUARDIAN INFORMED CONSENT FOR \\ PARENT AND CHILD PARTICIPATION
}

Dear Parent/Guardian:

This year, families at Fernwood Elementary School and seven surrounding childcare centers will be invited to participate in a family involvement study. The study is designed to identify promising familyinvolvement strategies intended to connect home and school environments to help children develop and improve their early literacy knowledge and reading readiness. A secondary purpose of the study is to determinc if lamily coaching increases parental self-efficacy, encouragement, and reinforcement. All parents/guardians of children in PreKindergarten (children born before September 1, 2001) and Kindergarten are invited to participate.

During the 2005-2006 school year, families will be randomly selected to participate in threc family institutes. Families selected to participate in the institutes will be asked to (a) attend bi-weekly work-shops, (b) conduct family literacy activities at-home, and (c) engage in family-friendly activities in the community. Using a coaching model, the bi-weekly workshops will include dinner, family discussions addressing various parenting topies, and literacy-focused activities. Families will leave each workshop with books, materials, and activities to do with their children ai-home and in the community.

Parents will also be asked to participate in two parent interviews, one in the fall and one in the spring. Each interview will take about one hour and will be arranged at a time convenient to you. The kinds of qucstions we will ask include background information about you and your child, your houschold routines, activities you do with your child, and your feelings. These questions will help us understand the role you play in your child's development. You do not have to respond to any question you do not wish to answer. In appreciation for your time, wo will give you $\$ 10$ for each interview completed.

We would also like to evaluate your child's language and learning skills. In the fall and spring of this school year, we will administer tests of vocabulary, letter sound, and emergent reading skills. 'Tbese tests will be given at your child's school during a time arranged with the teacher and will take about 30 minutes. The assessments will be administered by the teacher or a trained assessor. Your child does not have to respond to any question he/she does not want to answer. We will also obtain information from your child's teacher about his/her learning behavior. The results will be used to assess the impact of the Fernwood Elementary program and will not become a part of your child's school records. There is no risk to your child's participation. 
All information from the parent intervicw and the child assessments will be kept confidential. Your participation and your child's participation in this study are voluntary. You may stop participating at any time without penalty.

After you and your child participate in the study, we may ask your child's school to provide the following information: academic grades, referral for exceptional education services, statewide standardized assessment results, and/or retention information.

If you have any questions about the study, please call Dr. Rebecca England (FIE Family Involvement Specialist) or Dr. Madelaine Cosgrove (FIE Associate Director for School Readiness) at the Florida Institute of Education at the Universily of North Florida at (904) 620-2496. You may get more information about UNF policies, the conduct of this study, and your rights as a participant from Dr. Kathaleen Bloom, chair of the UNF Institutional Review Board (IRB) at 1-904-620-2455.

\section{STATEMENT OF INFORMED CONSENT}

I have read (or someone read to me) the information above and have had an opportunity to ask and have answered my questions.

By signing this form, I willingly agree for me (family institutes and interview) and my child (assessments and teacher rating scale) to take part in the Fernwood Family Involvement and Early Learning Hub study.

Child's Name:

Child's Birthdate:

Name of Parent (Legal Guardian):

Signature of Parent (Legal Guardian):

School Name: 
Appendix E

Participant Invitational Flyer 


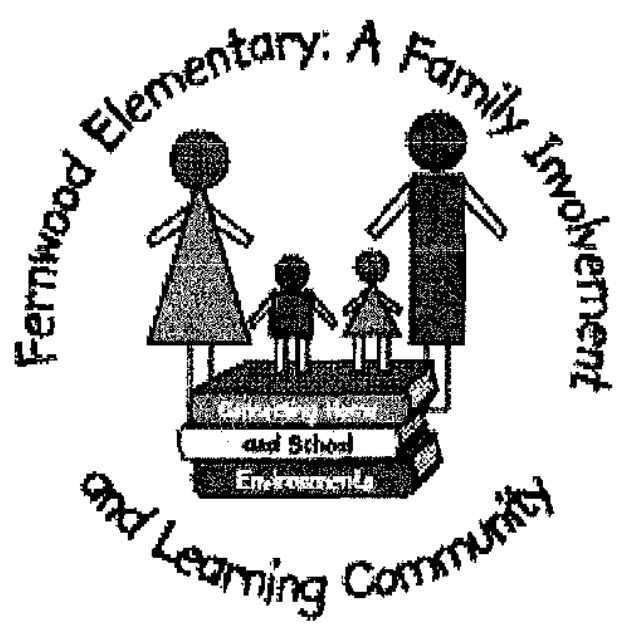

Please join us this Thuredoy for our second Thursday night session!

If Tuesday nights are more convenient for you - please join us next Tuesday. Feb. $7^{\text {th }}$ at 6:00!

To the family of:

\section{THIS THURSDAY IS OUR SECOND FAMILY WORKSHOP!}

\section{Thursday, February 2, 2006}

We are excited about our workshop and are looking forward to seeing you there.

TIME: 6:00 pm-8:00 pm

PLACE: Fernwood Elementary School Media Center

Signs will be posted at the school to lead you in the right direction! $A$ map to S. P. Livingston is on back.

DON'T FORGET: Dinner will be served, childcare will be provided, and door prizes will be given away!

().) See you THURSDAY at 6:00 pm! Be on time and be eligible for a DOOR PRIZE!! 
Appendix $\mathrm{F}$

Participant's General Information Form 


\section{GENERAL INFORMATION CARD}

Your Name:

Child's Name:

Child's School:

Do you work? If yes, what is your job?

What hours do you work?

Circle any groups with which you are involved. Church Sororities Fraternities

Child's School Sports Clubs Volunteer Groups Other

Which of these would your family enjoy? (Check all that apply.)

Museum of Science and History ___ Zoo movies

Adventure Landing

Miniature Golf

Chuck E Cheese Hands-on Museum Live Play Other (please list)

How many children under the age of 12 live in your home?

Please list the ages of the children.

What is your race?

What is your PreKindergarten/Kindergarten child's race? 
Appendix G

FCI Schedule Preference Form 
Thank you for becoming a part of the Fernwood Elementary: A Family Involvement and Learning Community!

Your Name:

Phone Number (where we are MOST LIKELY to reach you)

1. Our family workshops will be on Tuesdays and Thursdays. Which of those two days works best for you? (Circle one)

Tuesday or Thursday

2. What time of day is most convenient for you to attend the two-hour workshops?

Morning Afternoon Evening

Time:

3. Please list the names and ages of children you would bring to childcare during the workshops. 
Appendix $\mathrm{H}$

Parental Self-Efficacy for Helping the Child Succeed in School Scale 
Survey instrument deleted, paper copy available upon request. 
Appendix I

Parent Report of Encouragement Scale 
Survey instrument deleted, paper copy available upon request. 
Appendix J

Original Parent Report of Reinforcement 
Survey instrument deleted, paper copy available upon request. 
Appendix K

Family Involvement Learning Survey 


\section{Family Involvement and Learning Survey}

Dear Participant: the survey presented below is designed to assess the impact of the Fernwood Elementary: A Family Involvement and Learning Community: Family Coaching Institute on attitudes and behaviors of program participants. The information you provide will be kept confidential. While we would like for you to answer all the questions, you may decide to omit onc. Your participation is voluntary.

Instructions: Below are a number of statements that describe ways participation in the Family Coaching Model may have influenced your attitudes and bchaviors about learning at home. Please respond by indicating the extent of your agreement, on a scale of $1-10$, to the five statements below. The more you disagree with a statement the lower the number you would use, the more you agree with a statement the higher number you would use. Please write out your answer for question \#6.

Strongly

Disagree

1.

2.

3.

4.

5.

\section{2} 3 4 Participation in the Family Coaching Institute led me to change the way I think about what helping my child succecd in school means. Participation in the Family Coaching Institute increased my confidence in my ability to help my child learn at home.

Participation in the Family Coaching Institute increased my knowledge of ways to help my child at home.

Participation in the Family Coaching Institute has led me to spend more time helping my child learn at home.

Participation in the Family Coaching Institute has led me to turn everyday experiences into learning opportunities for my child.

6. For me the most important aspect of the Family Coaching Institute was

By complcting and submitting this survey I am consenting to participate in this rescarch study. 
Appendix L

Permission to Modify Scales 
From:

Sent:

To:

Subject:

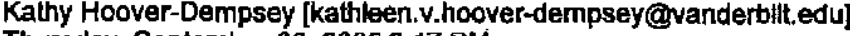
Thursday, September 08, 2005 2:17 PM

Green, Chrlsta Lynn; Young, James

Re: FW: Doctoral Student from Jax

H1 James,

I couldn't have said it better than Christa; it makes great sense to modify the items for your younger population; plloting on a younger population sample will glve you good info on reliability of the scales as you've modifled them; and it will be good to roport both the scales twith

reliabllities) from our work that you began with AND the adapted scales used with your population and the reliabilities you obtained for the adapted scales.

I have indeed been a bit swamped and thasks so much for checking in with Christa on this.

All best wisheg in the next stages of your proposal and study!

Kathy

At 10:27 AM 9/8/2005, Green, Christa Lynn wrote:

$>$ Absolutely! Feel free to modify the scales for your particular

spopulation. As you no doubt realized, it wouldn't make much sense to

$>$ use the scales for a population it wasn't designed for. While the

>validity and reliability remain the same for the scales we developed

$>$ with the population we used, using a different population (and

>subsequently modifying the scale) will change the reliability and

>validity of the scales for your use, but those should be easy for you

>to assess. It 1s important that you do pilot work to ensure good

$>$ reliability and validity with the modified scales.

$>$ To recap, I think (and Kathy can correct this if I'm wrong) that you

$>$ should modify the scale to make it meaningful for your population.

$>$ When writing about the scales, it is correct to use the reliability and

>validity information we have provided (stating explicitly that we used

$>a$ different population). Then it would be correct for you to say that

>you modified it, and after piloting the measure, found good/bad

>reliablifty and validity information that reflect/do not reflect the orlginal measure.

$>$

>Hope this helps! Good luck with the proposal. Christa

$>$

$>$

$>$

$>-$-On Thursday, September 8, 2005 11:02 AM -0400 "Young, James"

$>\langle j$ joungeriail.clay,k12,fl, us> wrote:

$>$

$>$

$\rightarrow$

>I sent this email to Dr. Hoover-Dempsey. She may not be there.

$>>$ Can you find the answers to my questions?

$>>$

$>$

$>$

$>$ Thanks

$\gg$

$\gg$

$>$

$>>$ James Young, Jacksonville

$>$ 
Appendix M

Modified Parental Self-Efficacy for Hclping the Child Succeed in School Scalc. 
Survey instrument deleted, paper copy available upon request. 
Appendix N

Modified Parent Report of Encouragement Scale 
Survey instrument deleted, paper copy available upon request. 
Appendix O

Modified Parent Report of Reinforcement 
Survey instrument deleted, paper copy available upon request. 


\section{References}

Alcxander, K. L., \& Entwisle, D. (1996). Family type and children's growth in reading and math over the primary grades. Journal of Marriage and Family, 58, 341-355.

Anderson, S. A. (2000). How parents involvement makes a difference in reading achievement, Reading Improvement, 37, 61-86.

Barrera, J. (2002). An investigation into parent involvement strategies employed by principals in bilingual public schools. Unpublished doctoral dissertation, Sam Houston State University, IIuntsville, TX.

Barrera, J. M., \& Warner, L. (2006). Involving parents in school events. Kappa Delta Pi Record. 42(2), 72-75.

Becher, R. M. (1984). Parent involvement: Review of research and principles of successful practices. Urbana, IL: ERIC Clcaringhousc on Elementary and Early Childhood Education. (ERIC Document Reproduction Service No. ED247032)

Becker, H., \& Epstein, J. (1982). Parent involvement: A survey of teacher practiccs. Elementary School Journal, 83(2), 85-102.

Benard, B. (1991). Fostering resiliency in kids: Protective factors in the family, school, and community. Portland, OR: Western Center for Drug-Free Schools and Communities. (ERIC Document Reproduction Scrvice No. ED335 781)

Benard, B. (1993). Fostering resiliency in kids. Educational Leadership, 5l(3), 44-48.

Berkowitz, M. W., \& Bier, M. C. (2005). Character education: Parents as partners. Educational Leadership, 63(1), 64-69.

Berliner, B., \& Benard, B. (1995). More than a message of hope: A district-level policymaker's guide to understanding resiliency. Portland, OR: Western Regional Center for Drug-Free School and Community. (ERIC Document Reproduction Scrvicc No. ED387 946)

Bloir, K. (1997). Parenting that promotes resilient urban African American families: Scholars describe the characteristics of their parents' parenting behaviors. Papcr presented at the annual conference of the National Council on Family Relationships, Arlington, VA. (ERIC Document Reproduction Service No. ED419 596)

Brody, G. H., \& Flor, D. L. (1998). Maternal resources, parenting practices, and child competence in rural single-parent African Amcrican families. Child Development, $69,803-816$. 
Callahan, K., Rademacher, J., \& Hildreth, B. (1998). The effect of parent participation in strategies to improve the homework performance of students who are at risk. Remedial and Special Education, 19(3), 131-41.

Carey, N., Lewis, L., \& Farris, E. (1998). Parent involvement in children's education: Efforts by public elementary schools (National Center for Education Statistics Statistical Analysis Report). Washington, DC: U.S. Government Printing Office.

Catsambis, S. (1998). Expanding the knowledge of parental involvement in secondary education: Effects on high school academic success (Report No. 27). Baltimore, MD: Center for Research on the Education of Students Placed at Risk. (ERIC Document Reproduction Service No. ED426 714)

Chen, X. (2001). Efforts by public k-8 schools to involve parents in children's education. Do school and parent reports agree? (Statistical Analysis Report). Washington, DC: National Council for Education Statistics.

Clark, P. B. (1989). Involving parents in the education of their children. Urbana, IL: ERIC Clearinghouse on Elementary and Early Childhood Education. (ERIC Document Reproduction Service No. ED308988)

Colgan, K. (2002). Parental involvement in reading development. Unpublished masters thesis, Kean University, Union, NJ.

Comer, J. (1989). Child development and education. Journal of Negro Education, 58(2), $125-39$.

Comer, J. P., \& Haynes, N. M. (1991). Parent involvement in schools: An ecological approach. Elementary School Journal, 91, 271-278.

Comer, J. P., \& Haynes, N. M. (1999). The dynamies of school change: Response to the article "Comer's School Development Program in Prince George's County, Maryland: A theory-based evaluation," by Thomas D. Cook et al. American Educational Research Journal, 36, 599-607.

Cook, T., Habib, F., Phillips, M., Settersten, R. A., Shagle, S. C., \& Degirmencioglu, S. M. (1999). Comer's School Development Program in Prince George's County Maryland: A theory-based evaluation. American Educational Research Journal, 36, 543-597.

Council of the Great City Schools. (1995). Comer School Development Program. A collaborative effort between the San Diego State University and the San Diego Unified School District to implement the Comer School Model Program. Retrieved April 19, 2003, from www.cgcs.org/promise/whatworks/reform/part.ht 
Crane, J. (1996). Effects of home environment, SES, and maternal test scores on math achievement. Journal of Educational Research, 89, 305-314.

Crnic, K., \& Booth, C. (1991). Mothers' and fathers' perceptions of daily hassles of parenting across early childhood. Journal of Marriage and Family, 53, 1042-50.

Davis, G. (2005). Using Retrospective pre-post questionnaire to determine program impact. Journal of Extension, 41(4).

Desimone, L. (1999). Linking parent involvement with student achievement: Do race and income matter? Journal of Educational Research, 93(1), 11-29.

Donovan, J. (1992). The Hunter Model: A four year longitudinal study of staff devclopment cffects. Journal of Research and Development in Education, 25(3), $165-172$.

Eccles, J., \& Harold, R. D. (1993). Parent-school involvement during the early adolescent years. Teachers College Record, 94, 568-87.

Eccles, J. S., \& Harold, R. D. (1996). Family involvement in children's and adolescents' schooling. In A. Brooth \& J. F. Dunn (Eds.), Family-school links: How do they affect educational outcomes? (pp. 3-34). Mahwah, NJ: Lawrence Erlbaum Associates.

Education Commission of the Statcs. (1995). Direct instruction. Retrieved November 25, 2005, from http://www.ecs.org

Entwisle, D. R., \& Alexander, K. L. (1992). Summer setbacks - race and poverty school composition, and mathematics achievement in the $1^{\text {st }}$ two years of school. American Sociological Review, 57(1), 72-84.

Epstcin, J. L. (1984, April). Effects of teacher practices of parent involvement change in student achievement in reading and math. Paper presented at the Annual Meeting of the American Educational Research Association. (ERIC Document Reproduction Service No. ED256863)

Epstein, J. L. (1986). Parents' reactions to teacher practices of parent involvement. Elementary School Journal, 86, 277-94.

Epstein, J. L. (1987). Parent involvement. What research says to administrators. Education and Urban Society, 19(2), 119-136.

Epstein, J. L. (1992). School and family partnerships (Report No. 6). Baltimore, MD: Johns Hopkins University, Center on Families, Communities, Schools, and Children's Learning. (ERIC Document Reproduction Service No. ED43715) 
Epstein, J. L. (1995). School/family/community partnerships: Caring for the children we share. Phi Delta Kappa, 76, 701-712.

Epstein, J. L., Coates, L., Salinas, K., Sanders, M., \& Simon, B. (1997). School, family, and community partnerships: Your handbook for action. Thousand Oaks, CA: Sage.

Epstein, J. L., \& Dauber, S. L. (1991). School programs and teachers practices of parental involvement in inner-city elementary and middle schools. Elementary School Journal, 9l(3), 289-303.

Epstein, J. L., \& Sheldon, S. B. (2001, August). Foctus on math achievement. Effects on family and community involvement. Paper presented at the annual mceting of American Sociological Association, Anaheim, CA.

Epstein, J. L., \& Sheldon, S. B. (2002). Present and accounted for. Improving student attendance through family and community involvement. Journal of Educational Research, 95, 308-318.

Fan, X., \& Chen, M. (2001). Parent involvement and students' academic achievement. A meta-analysis. Educational Psychology Review, 13(1), 1-22.

Florida Department of Education. (1999). FCAT, Retrieved November 25, 2005, from http://firn.edu/doe/sas/fcat.htm

Garmczy, N. (1994). Resiliency and vulnerability to adverse developmental outcomes associated with poverty. Journal of Research on Adolescence, 4(1), 71-97.

Griflith, J. (1996). Relationship of parent involvement, empowerment, and school traits to students' academics performance. Journal of Educational Research, 90(1), 3341 .

Gutman, L. M., \& McLoyd, V. C. (2000). Parent's management of their children's Education within the home at school and in the community: An examination of African American families living in poverty. Urban Review, 32(1), 1-24.

Harris, M., \& Wheeler M. A. (1997). Promising practices: The Pride Program at Bloomsburg University of Pennsylvania. Multicultural Education, 5(2), 20-22.

Hart, T. E. (1998). Involving parents in the education of their children. OSSC Bulletin, $32(3), 1-48$.

Hayes, N. M., Emmons, C. L., \& Woodruff, D. W. (1998). School development program effects: Linking implementation to outcomes. Journal of Education for Students Placed at Risk, 3(1), 71-85. 
Henderson, A. T. (1987). The evidence continues to grow. Parent involvement improves student achievement. Columbia, MD: National Committee for Citizens in Education. (ERIC Document Reproduction Service No. ED315199)

Henderson, A. T., \& Berla, N. (1994). A new generation of evidence: The family is critical to student achievement. Washington, DC: National Committce for Citizens in Education. (ERIC Document Reproduction Service No. ED375968)

Hester, H. (1989). Start at home to improve home-school rcadiness. NASSP Bulletin, 73(513), 23-27.

Hiebert, J., \& Stigler, J. W. (2000). A proposal for improving classroom teaching: Lessons from the TIMMSS video study. Elementary School Journal, 101(1), 320.

Hoover-Dempsey, K. V., \& Sandler, H. M. (1995). Parent involvement in children's education: Why does it make a difference? Teachers College Record, 97(2), 310331.

Hoover-Dempsey, K. V., \& Sandler, H. M. (1997). Why do parents become involved in thcir children's education? Review of Educational Research, 67(1), 3-42.

Hoover-Dempsey, K. V., \& Sandler, H. M. (2002). Teachers Involving Parents (TIP): Results of an inservice teacher education program for enhancing parental involvement. Teaching and Teacher Education, 18, 843-67.

Hoover-Dempsey, K. V., \& Sandler, H. M. (2005, March). Final performance report for OERI rrant \# R305T010673: The social context of parental involvement: A path to enhanced achievement. Presented to Project Monitor, Institute of Education Sciences, U.S. Department of Education, March 22, 2005.

Hoover-Dempsey, K.V., Walkcr, J. M., Sandler, H. M., Whetsel, D., et al. (2005). Why do parents become involved? Research findings and implications. The Elementary School Journal, 106(2), $105-132$.

Horn, L., \& West, J. (1992). A profile of parents of eighth graders. National Education Longitudinal Study of 1988 (Statistical Analysis Report). Berkeley, Ca: MPR Associates. (ERIC Document Reproduction Service No. ED350341)

Horvat, E. M., Weininger, E. B., \& Laureau, A. (2003). From social ties to social capital: Class differences in the relationships between schools and parent networks. American Educational Research Journal, 40(2), 319-351.

Howard, G. S. (1980). Response shift bias A problem in evaluating intervention with pre/post self-response. Evaluating Review, 4(1), 93-106. 
Huang, G., Sameena, S., Peng, S., \& Owings, J. (1996). National Educational Longitudinal Study of 1988 (NELS 1988). Research Framework and Issues, National Center for Educational Statistics Working Paper NO. 96-03. Washington, DC: National Center for Educational Statistics.

Huang, S. L., \& Waxmen, H. C. (1996). Learning environment differences between high and low-achieving minority students in urban middle schools. Washington, DC: Office of Education and Research and Improvement. Eisenhower Program for Math and Science Education. (ERIC Document Reproduction Service No. ED398314)

Jordan, G., Snow, C., \& Porche, M. (2000). Project EASE: The effect of a family literacy project on kindergarten students' early literacy skills. Reading Research Quarterly, 35, 524-46.

Juel, C. (1988). Learning to read and write: A longitudinal study of 54 children from first through fourth grades. Journal of Educational Psychology, 80(4), 437-447.

Keith, T. Z. (1993). Does parental involvement affect eighth-grade student achievement? Structural analysis of national data. School Psychology, 22, 474-96.

Kiley, T. (1995). A study of attitudes among the parents of primary-school children. Boston: Kiley.

Koonce, D. A., \& Harper, H., Jr. (2005). Engaging African Americans in the schools: A community consultation model. Journal of Educational and Psychological Consultation, $16(1 \& 2), 55-74$.

Kozol, J. (1991). Savage inequalities. New York: Harper Perennial.

Laureau, A. (1989). Home advantage: Social class and parent involvement in elementary education. New York: Basic.

Lee, V. (1991). Academic behaviors among high-achicving African-American students. Echucation and Urban Society, 24(1), 65-86.

Leitch, M. L., \& Tangri, S. S. (1988). Barriers to home-school collaboration. Educational Horizon, 66(2), 70-74.

Malloy, W., \& Rayle, J. (2000). The Comer process to create a successful middle school. Middle School Journal, 31(5), 12-18.

Masten, J. (1994). Life events and adjustment in adolescents: The significance of event independence, desirability, and chronicity. Journal of Research on Adolescence, $4(1), 71-97$. 
Mattingly, D. J., Prislin, R., McKenzie, T. L., Rodriguez, J. L., \& Kayzar, B. (2002). Evaluating evaluations: The case of parent involvement programs. Review of Educational Research, 72(4), 549-576.

McLanahan, S., \& Sandefur, G. (1994). Growing up with a single parent. What hurts, what helps. Cambridge, MA: Harvard University Press.

McNeal, R. B. (1999). Parental involvement as social capital: Differential effectivencss on science achievement, truancy, and dropping out, Social Forces, 78(1), 117144.

Milne, $\Lambda$. (1986). Single parents, working mothers, and the educational achievement of school children. Sociology of Education, 59(3), 125-39.

Morrow, L., \& Young, J. A. (1997). Family literacy program connecting school and home: Effects on attitude, motivation, and literacy achievement. Journal of Educational Psychology, 89, 736-42.

Muller, C., \& Kerbow, D. (1993). Parent involvement in the home, school, and community. In B. Schncider, \& J. S. Coleman, J. S. (Eds.), Parents, their children, and schools (pp. 13-42). Boulder, CO: Westview.

Nathan, J. (2005). Charters "yes!" vouchers "no!" Parental choice and excellence. Educational Horizons, 83(2), 110-124.

Neufeld, B., \& Roper, D. (2003). Expanding the work: Year II of collaborative coaching and learning in the effective practice schools. Boston, MA: Coaching for Improved Teaching Collegial Teaching. (ERIC Document Reproduction Service No. ED480 874)

Olmsted, P. P. (1991). Parent involvement in elementary education: Findings and suggestions from the Follow Through program. Elementary School Journal, 91 (3), 221-231.

Payne, K. L., \& Biddle, B. J. (1999). Poor school funding, child poverty, and mathematics achievement. Educational Researcher, 28(6), 4-13.

Peng, S. S., \& Lee, R. M. (1992). Demographic disparities of inner-city eighth graders. Urban Education, 26, 441-59.

Pohl, N. F. (1982). Using retrospective pre-ratings to counteract reponse-shift confounding. Journal of Experimental Education, 50(4), 1-214.

Public Law 103.227 (1994), Goals 2000. Educate America Act. 103 Congress. 
Reynolds, A. J., Temple, J. A., \& Miedel, W. T. (2002). Can early intervention prevent high school drop outs? Evidence from the Chicago Child-Parent Centers. Urban Education, 35(1), 31-56.

Reynolds, A., Temple, J., Robertson, D., \& Mann, E. (2001). Long term effects of an early childhood intervention on educational achievement and juvenile arrest: A 15-year follow-up of low-income children in public schools. JAMA, 285, 2339-46.

Rockwell, S. K., \& Kohn, H. (1989). Post-then pre-cvaluation. Journal of Extension, 27(2), 19-21.

Rohs, F. R. (1999). Response shift bias: A problem in evaluating leadership development with self-reported pretest-posttest measures. Journal of Agricultural Education, $40(4), 28-37$.

Ross, J. (1992). Teacher efficacy and the effects of coaching on student achievement. Canadian Journal of Education, 17(1), 51-65.

Sanders, M. G. (2001). The role of community in comprehensive school, family, and eommunity partnership programs. Elementary School Journal, 102(1), 19-34.

Schefter, C. A. (2001). Parental involvement and its effects on student reading achievement. Master's Research Project, Kean Universily. (ERIC Document Reproduction Service No. ED451 475

Seligman, L. (1991). The career devclopment of 10 year olds. Elementary School Guidance and Counseling, 23, 172-81.

Sheldon, S. B. (2002). Parents' social networks and beliefs as predictors of parent involvement. Elementary School Journal, 102, 301-316.b

Sheldon, S. B. (2003). Linking school-family-community partnerships in urban elementary schools to student achievement on state test. The Urban Review, 35(2) 149-152.

Sheldon, S. B. (2005). Involvement counts: Family and community partnerships and achievement. Journal of Educational Research, 98(4), 196-206.

Sheldon, S. B., \& Epstein, J. L. (2003, April). School programs of family and community involvement in children's reading and literacy development. Paper presented at the Developing Literacy for Students in Urban Schools: Research and Policy, International Reading Association and Urban Partnership Mini-conference, San Diego State University, San Dicgo, CA. 
Sheldon, S. B., \& Van Voorhis, F. L. (2001, August). Identifying essential elements of school partnership programs and effects on family involvement. Paper presented at the annual meeting of the Amcrican Sociological Association, Anaheim, CA.

Simon, B. S. (2000). Predictors of high school and family partnerships and the influence of partnerships on student success. Unpublished doctoral dissertation, Johns Hopkins University, Baltimorc.

Smith, S. W. (2001). Involving parents in the IEP process. Arlington, VA: ERIC Clearinghouse on Disabilities and Gifted Education. (ERIC Document Reproduction Service No. ED455 658)

Smokowski, P., Reynolds, A., \& Bezruczko, N. (1999). Resilience and protective factors in adolescence: An autobiographical perspective from disadvantaged youth. Journal of School Psychology, 37, 425-48.

Stein, M. R. S., \& Thorkidscn, R. J. (1999). Parent involvement in education: Insights and applications from the research. Bloomington. IN: Phi Delta Kappa International.

Stevenson, D. L., \& Baker, D. P. (1987). The family-school relationship and the child's school performance. Child Development, 58, 1348-1457.

Thompson, S., \& Ross F. (2000). Bccoming a teacher in a professional development school. Teaching and Change, 8(1), 31-50.

Turner, J. (2000). Parent involvement: What can we learn from research? Montessori Life, 12(2), 37-39.

United States Bureau of the Census. (2000). Data profiles 2000. Retrieved April 19, 2003, from http://www.census.gov.acs/www/Products/Single/2000/ACS/ index.ht

U. S. Department of Education. (1994). Strong families, strong schools: Building community partnerships for learning. A research base for family involvement in learning. Washington, DC: Author.

Van Voorhis, F. L. (2001). Interactive science homework: An experiment in home and school connections. NASSP Bulletin, 85(2), 20-32.

Wang, M., Haertel, G. D., \& Walberg, H. J. (1997). Fostering educational resilience in inner-city schools (Publication series No. 4). Philadelphia: Mid-Atlantic Lab for Student Success. (ERIC Document Reproduction Service No. ED419 856)

Wang, M., Haertel, G., \& Walberg, H. (1998). Achieving student success: A handbook of widely implemented research-based educational reform models (Publication Series No. 12). Washington, DC: Mid-Atlantic Lab for Student Success. Office of 
Education and Research and Improvement. (ERIC Document Reproduction Service No. ED440 443)

Yap, M., \& Enoki, D. Y. (1994). In search of the elusive magic bullet: Parental involvement and student outcomes. School Community Journal, 5(2), 97-106. 


\section{VITA}

\section{James Young}

Educational and Professional Experience

\section{Academic Degrees}

University of North Florida

Ed.D. Educational Leadership, 2007

Jacksonville, Florida

Jacksonville University

M.A.T. Educational Leadership, 1997

Jacksonville, Florida

Savannah State College

B.S. Biology, 1991

Savannah, Georgia

\section{Professional Experience}

Orange Park Jr. High

Orange Pak Florida

Rufus Payne Elemcntary

Jacksonville, Florida

Pine Estates Elementary

Jacksonville, Florida

Andrew Robinson Elementary

Jacksonvillc, Florida

Wolfson High School

Jacksonville, Florida

Fletcher High School

Jacksonville Beach, Florida

Winder-Barrow Middle School Science

Winder, Gcorgia

United States Marine Corps
Principal, 2005-Present

Principal, 2002-2005

Principal, 1999-2002

Vice Principal 1997-1999

Assistant Principal,1996-1997

Science Teacher, 1993-1996

Science/Reading Teacher, 1992-1993

1986-1992 
Principal

Rufus Payne Elementary

Duval County

Jacksonville, Florida

Principal

Orange Park Jr. High

Clay County

Orange Park, Florida 